ISSN 0081-7147

e-ISSN 2451-1331

\author{
Marcin HLEBIONEK \\ https://orcid.org/0000-0002-7047-4143 \\ Uniwersytet Mikołaja Kopernika w Toruniu
}

\title{
Nieznana pieczęć królowej Barbary Zapolyi na tle sfragistyki małżonek królów polskich z dynastii Jagiellonów*
}

Zarys treści: Artykuł składa się z dwóch części. W pierwszej uporządkowano wiedzę na temat sfragistyki królowych polskich czasów jagiellońskich, począwszy od Jadwigi Andegaweńskiej po królową Bonę Sforzę. W drugiej części analizie w kategoriach heraldyki oraz znaku tożsamości poddano nieznaną dotąd pieczęć królowej Barbary Zapolyi (1495-1515), pierwszej żony króla Zygmunta I.

\begin{abstract}
The article is divides into two parts. The first one organises the knowledge of the sphragistics of Polish queens of the Jagiellonian times, from Queen Jadwiga to Queen Bona Sforza. The second part analyses, in terms of heraldry and the sign of identity, a hitherto unknown seal of Queen Barbara Zápolya (1495-1515), the first wife of King Sigismund I the Old.
\end{abstract}

Slowa kluczowe: Jagiellonowie, pieczęcie królowych, sfragistyka, Zapolya (ród), heraldyka, status społeczny, tożsamość

Keywords: Jagiellons, queens' seals, sphragistics, Zápolya House, heraldry, social status, identity

Pieczęcie polskich królowych już w XIX w. notowano w katalogach pieczęci królewskich obok sigillów koronowanych małżonków ${ }^{1}$, ale rzadko stawały się one przedmiotem osobnych

\footnotetext{
* Artykuł powstał w ramach projektu „Epoka jagiellońska i jej dziedzictwo w I Rzeczypospolitej do 1795 r. - historia sztuki, kultury materialnej, dzieje piśmiennictwa XIV-XVI wiek", finansowanego z Narodowego Programu Rozwoju Humanistyki, umowa nr 0467/NPRH5/H30/84/2017.

1 T. Żebrawski, O pieczęciach dawnej Polski i Litwy, Kraków 1865, s. 39, nr 41; s. 40, nr 42; s. 41, nr 43; s. 48, nr 49; s. 62, nr 75; K. Stronczyński, Pobieżny przegląd pieczęci Piastów polskich, Warszawa 1881, s. 50, 59, 60, 64; F. Piekosiński, Pieczęcie polskie wieków średnich, Kraków 1899, s. 204, nr 347; s. 288, nr 580; tenże, Pieczęcie polskie wieków średnich doby piastowskiej (uzupetnienie), Kraków 1936, s. 24-25, fig. 475; E. Diehl, Uzupelnienie do sfragistyki polskiej, „Wiadomości Numizmatyczno-Archeologiczne", 2, 1890, nr 4, szp. 111, rys. 6; szp. 112, rys. 7; szp. 120, rys. 12; tenże, Przyczynek do sfragistyki polskiej, „Wiadomości Numizmatyczno-Archeologiczne”, 8, 1896, nr 6, szp. 115-116, fig. 8; I. Sułkowska-Kurasiowa, Polska kancelaria królewska w latach 1447-1506, Wrocław-Warszawa-Kraków 1967, s. 71-72, 74, 76; Documenta ex archivo Regiomontano ad Poloniam spectantia, wyd. C. Lanckorońska, Elementa ad fontium editiones, t. 30, Romae 1973, tab. V-VI; I. Sułkowska-Kurasiowa, Dokumenty królewskie i ich funkcja w państwie polskim za Andegawenów i pierwszych Jagiellonów 1370-1444, Warszawa 1977, s. 43-44, 65-67; M. Koczerska, Opisy pieczęci Jagietly i Jadwigi w widymacie Zbigniewa Oleśnickiego z 1427 roku, w: Heraldyka i okolice, red. A. Rachuba, S. Górzyński, H. Manikowska, Warszawa 2002, s. 229-254; Imagines potestatis. Insygnia i znaki władzy w Królestwie Polskim i Zakonie Niemieckim. Katalog wystawy w Muzeum Zamkowym w Malborku 8 czerwca - 30 września 2007 roku, red. J. Trupinda, Malbork 2007, nr III.3.34, III.3.35,
} 
studiów ${ }^{2}$. Sytuacja taka nie jest charakterystyczna wyłącznie dla polskiej sfragistyki. Braki w studiach nad pieczęciami kobiecymi w ogóle, a pieczęciami królowych w szczególności zauważają także autorzy zachodnioeuropejscy ${ }^{3}$. Sytuację tę trafnie scharakteryzowała Andrea Stieldorf wciąż aktualnym cytatem z Johanna Christopha Gatterera: ,at enim ipsa earum [tj. królowych - M.H.] sigilla vel temporis edacitate consumta, vel a diplomatum editoribus neglecta fuerunt" ${ }^{\prime 4}$ W naszym przypadku taki stan rzeczy powoduje, że nie zawsze jesteśmy w stanie nie tylko wystarczająco precyzyjnie określić kształt systemu sfragistycznego królowych, ale też prześledzić procesy rozwojowe ikonografii tworzących go elementów. A przecież częste przypadki, kiedy jeden monarcha miał kolejno wiele małżonek, powodowały, że to właśnie pieczęcie królowych były szczególnie wrażliwe na mody stylistyczne. Analiza ich sfragistyki pozwala ponadto na uzupełnienie wiedzy na temat systemu symboli władzy wykorzystywanego w ramach danej dynastii, umożliwiając nie tylko uchwycenie jego elementów pozostających poza głównym nurtem (którego centrum była osoba króla), ale też, dzięki nierzadkim zmianom typariuszy, na wskazanie genezy nowych rozwiązań w nim się pojawiających ${ }^{5}$. Pieczęcie te stanowią wreszcie niezwykle ważny materiał do rozważań nad statusem oraz tożsamością dysponentek. Badania nad pieczęciami dynastii Jagiellonów pozwalają na ostrożny wniosek, że po zawarciu małżeństwa dynastycznego kobieta w sferze sfragistyki albo przyjmowała wzorce obowiązujące na dworze męża, albo też wprowadzała nowe zwyczaje, wywodzące się z kręgu kulturowego, w którym została wychowana ${ }^{6}$.

III.3.50, III.3.62; Pieczęcie królów i królowych Polski, Warszawa 2010, s. 14, 26, 39, 60-61, 82, 100, 118-123, 131-134, 149-151, 193; Sigilla regum et reginarum Poloniae. Pieczęcie królów i królowych Polski ze zbiorów Archiwum Głównego Akt Dawnych, Warszawa 2015, s. 15-16, 28, 44, 70-71, 117, 137-146, 153-157, 177-179, 227.

2 Próby podsumowania wiedzy na temat pieczęci królowych zawiera rozdział podręcznika sfragistyki autorstwa M. Gumowskiego, Pieczęcie królowych, w: M. Gumowski, M. Haisig, S. Mikucki, Sfragistyka, Warszawa 1960, s. 184-185, a także fragment niemieckojęzycznego wprowadzenia do polskiej sfragistyki tego autora, Handbuch der polnischen Siegelkunde, Graz 1966, s. 40-42 oraz ilustracje w tekście [nr 32] i na tabl. X-XI. Ostatnio na temat pieczęci królowych polskich związanych z władcami dynastii jagiellońskiej, w kontekście pieczęci Anny Jagiellonki, głos zabrał Z. Piech, Monety, pieczęcie $i$ herby $w$ systemie symboli władzy Jagiellonów, Warszawa 2003, s. 82-84. Herbowe pieczęcie królowych omówił tenże badacz w artykule poświęconym szerszemu problemowi funkcjonowania pieczęci herbowych: Pieczęcie herbowe $w$ systemach sfragistycznych dawnej Rzeczpospolitej, w: Dawne pieczęcie. Typologia - metody badań - interpretacje, red. Z. Piech, Warszawa 2015, s. 246-250. W kontekście interpretacji tablicy fundacyjnej kaplicy Trzech Hostii w kościele Bożego Ciała w Poznaniu do sfragistyki królowych nawiązał P. Stróżyk, Tablica herbowa z kościoła Bożego Ciała w Poznaniu, w: Memoria viva. Studia historyczne poświęcone pamięci Izabeli Skierskiej (1967-2014), red. A. Gąsiorowski, G. Rutkowska, Poznań 2015, s. 771-773. Do wyjątków należą studia poświęcone pieczęciom poszczególnych królowych. Wiedzę na temat pieczęci królowej Elżbiety Rakuszanki istotnie poszerza artykuł Z. Piecha poświęcony roli austriackiego herbu Habsburgów w heraldyce jagiellońskiej: Austriacki herb Habsburgów w heraldyce Jagiellonów, w: Nihil superfluum esse. Prace z dziejów średniowiecza ofiarowane Profesor Jadwidze Krzyżaniakowej, red. J. Strzelczyk, J. Dobosz, Poznań 2000, s. 565-594, oraz uzupełnienia do niego poczynione przez S. Szybkowskiego, Przyczynki do sfragistyki Jagiellonów na podstawie materiałów z Archiwum Państwowego w Gdańsku, „Rocznik Gdański”, 71/72, 2011-2012, s. 14-17. Osobnych opracowań doczekały się jedynie pieczęć przypisywana królowej Rychezie (ta nie tylko w polskiej literaturze, zob. G. Pac, Czy królowa Rycheza używała pieczęci?, Kwart. Hist., 122, 2015, nr 1, s. 5-38; tam wcześniejsze publikacje) oraz pieczęć królowej Ludwiki Marii Gonzagi (I. Kraszewski, Pieczęć herbowa królowej Ludwiki Marii jako zapis historii dynastycznej Gonzagów Niwereńskich, w: Pieczęcie herbowe - herby na pieczęciach, red. Z. Piech, W. Drelicharz, Warszawa 2011, s. 87-108).

${ }^{3}$ Zob. np. A. Stieldorf, Die Siegel der Herrscherinnen. Siegelführung und Siegelbild der „, deutschen” Kaiserinnen und Königinnen, „Rheinische Vierteljahrsblätter”, 64, 2000, s. 1; B. Bedos-Rezak, Women, Seals and Power in Medieval France 1150-1350, w: Women and Power in the Middle Ages, red. M. Erler, M. Kowaleski, Athens-London 1988, s. 61-64; E. Danbury, Queens and Powerful Women. Image of Authority, w: Good Impressions. Image and Authority in Medieval Seals, red. N. Adams, J. Cherry, J. Robinson, London 2008, s. 17. Przywołane tu publikacje zawierają wcześniejszą literaturę z kręgów niemieckiego, francuskiego i angielskiego. Zestawienie to można uzupełnić o informację dotyczącą publikacji t. 3 korpusu pieczęci francuskich, poświęconego pieczęciom francuskich rodzin królewskich, w tym królowych; zob. Corpus des sceaux français du Moyen Age, t. 3: Les sceaux des reines et des enfants de France, red. M.-A. Nielen, Paris 2011, ss. 365.

${ }^{4}$ A. Stieldorf, Die Siegel der Herrscherinnen, s. 1.

${ }^{5}$ W zbliżony sposób E. Danbury, Queens and Powerful Women, s. 17.

${ }^{6}$ Podobne spostrzeżenia sformułowała M. Kaganiec względem pieczęci Piastówien śląskich wydawanych za mąż za obcych władców; zob. taż, Heraldyka Piastów Śląskich 1146-1707, Katowice 1992, s. 136, 157. W kontekście pieczęci królowych Z. Piech zwrócił uwagę na „nawiązywanie [w sfragistyce królowych - M.H.] do rodzimych tradycji heraldyczno-sfragistycznych" jako jeden z czynników powodujących brak stabilizacji ich ikonografii; zob. tenże, Pieczęcie herbowe, s. 247. 
Wybór którejś ze ścieżek zależał niewątpliwie od pozycji, jaką zajmowała, wchodząc do nowej rodziny, tamtejszych obyczajów, jej osobowości, religijności, ale też atrakcyjności kręgu kulturowego, z którego się wywodziła.

\section{Pieczęcie żon Jagiellonów polskich do początku XVI w.}

Do tej pory znanych było dziesięć pieczęci używanych od końca XIV do połowy XVI w. przez królewskie małżonki związane z władcami Polski i Litwy z dynastii Jagiellonów, z wyłączeniem pieczęci małżonek Zygmunta Augusta ${ }^{7}$. Najliczniejszy wśród nich jest system sfragistyczny królowej Jadwigi Andegaweńskiej, która dysponowała przynajmniej sześcioma rodzajami pieczęci. Nie może to dziwić, zważywszy na fakt, że była ona królem Polski ${ }^{8}$. Stąd pomiędzy jej pieczęciami - wyjątkowo w skali interesującego nas zespołu źródeł - pojawia się pieczęć majestatowa9. Pozostałe pieczęcie królowej, przyjąwszy - za Zenonem Piechem - jako kryterium klasyfikacji złożoność zespołu herbów ${ }^{10}$, podzielić

${ }^{7}$ Pieczęcie Elżbiety i Katarzyny Habsburskiej, a także Barbary Radziwiłłówny, nie będą szczegółowo prezentowane w tej części artykułu. Odniesienia do nich i podstawowe informacje na ich temat znajdzie czytelnik w rozważaniach dotyczących sfragistyki i heraldyki królowej Barbary Zapolyi.

${ }^{8}$ R. Bubczyk, Charakterystyka wspótrządów Jadwigi Andegaweńskiej i Władysława II Jagietly w Polsce, ,Annales Universitatis Mariae Curie-Skłodowska”, 52-53, sectio F, 1997-1998, s. 29-47 (tam wcześniejsza literatura). Jednak już w XV w. pełnia władzy królewskiej Jadwigi była kwestionowana; zob. P. Węcowski, Jadwiga Andegaweńska w opinii prawniczej z końca XV wieku. Przyczynek do późnośredniowiecznych wyobrażeń na temat władzy monarszej, w: Ecclesia - regnum fontes. Studia z dziejów średniowiecza, red. S. Gawlas, K. Gołąbek, M. Janicki i in., Warszawa 2014, s. 250-257. Zgadzając się z Z. Piechem, Pieczęcie herbowe, s. 238, że kształt systemu sfragistycznego Jadwigi wynikał z jej szczególnego statusu, zdecydowałem się na krótkie omówienie jej pieczęci w kręgu sfragistyki królowych, ponieważ stanowią one punkt wyjścia dla pieczęci kolejnych żon Jagiełły, a także istotny punkt odniesienia dla pieczęci późniejszych królowych. Jednocześnie uważam, że zespół pieczęci używanych przez królową Jadwigę wymaga osobnej, pogłębionej analizy.

9 Średnica: 106 mm; legenda: zob. Aneks, nr 1; oryg.: AN, Archiwum Dzikowskie Tarnowskich, sygn. 5 (1385 r.); drugi egzemplarz jest przechowywany w Archiwum Krakowskiej Kapituły Katedralnej, a informacje o nim podaje KDKK, cz. 2, nr 329 (1386 r.); trzeci znany oryginał znajduje się w zasobie Archiwum Polskiej Prowincji Dominikanów w Krakowie, Zbiór dokumentów pergaminowych Prowincji Polskiej Zakonu Kaznodziejskiego i klasztoru krakowskiego, sygn. 92 (1386 r.); odlewy: Zakład Narodowy imienia Ossolińskich we Wrocławiu, Dział Numizmatyczny, Odlewy metalowe pieczęci, nr inw. 1587; Muzeum Narodowe we Wrocławiu, sygn. S-X-3273/M S; Zbiory sfragistyczne Zakładu Nauk Pomocniczych Historii Uniwersytetu Jagiellońskiego, sygn. D-418; literatura: F.A. Vossberg, Siegel des Mittelalters von Polen, Lithauen, Schlesien, Pommern und Preussen, Berlin 1854, s. 10-11, tabl. 6; T. Żebrawski, O pieczęciach, s. 39-40, nr 41, tabl. XVI; K. Stronczyński, Pobieżny przeglą, s. 64; M. Gumowski, Początki Orła Białego, Rocz. Hist., 7, 1931, tabl. XIV; W. Fabijański, Odlewy metalowe pieczęci w zbiorze sfragistycznym Zakładu Narodowego im. Ossolińskich. Katalog, Wrocław 1999, s. 18, nr 6, tabl. 5; Imagines potestatis, nr III.1.34; Album rysunków pieczęci Kajetana Wincentego Kielisińskiego ze zbiorów Biblioteki Kórnickiej Polskiej Akademii Nauk, wyd. P. Pokora, Kórnik 2013 [dalej: Album Kielisińskiego], s. 20, nr Ao I 18; Z. Piech, Pieczęcie herbowe, s. 238-239. W kontekście tej pieczęci Jadwigi warto zauważyć, że w średniowieczu na Węgrzech aż do końca panowania Andegawenów pieczęcie tronowe stanowiły stały składnik systemu sfragistycznego królowych; zob. Ch. Mielke, Every Hyacinth the Garden Wears. The Material Culture of Medieval Queens of Hungary (1000-1395), Budapest 2017, s. 23-46 (mszp niepublikowanej pracy doktorskiej, <http://www.etd.ceu.edu/2017/mielke_christopher.pdf> [dostęp: 20.09.2020], oraz katalog, tamże s. 390-426, nr I. 1, I. 2, I. 3, I. 4, I. 5, I. 6, I. 7, I. 9, I. 10, I. 12, I. 13, I. 17, I. 19, I. 20, I. 21 (tam wcześniejsza literatura). Dość często, szczególnie we wcześniejszym średniowieczu, typu tronowego używały cesarzowe i królowe niemieckie; zob. A. Stieldorf, Die Siegel der Herrscherinnen, s. 10-26. Znacznie rzadziej pojawiają się one w średniowiecznej Francji, Anglii czy Skandynawii (zob. B. Bedos-Rezak, Women, Seals and Power, s. 75; E. Danbury, Queens and Powerful Women, s. 18; Danske kongelige Sigiller samt sønderjydske Hertugers og andre til Danmark knyttede Fyrsters Sigiller 1085-1559, red. H. Petersen, A. Thiset, København, 1917, s. 1-20, tabl. 1-21; B.E. Hildebrand, Svenska sigiller från medeltiden, Stockholm 1862-1867, s. 1-10, P1. 1-11; Norske Sigiller fra Middelalderen, t. 2: Kongelige og fyrstelige segl, red. H.J. Huitfeldt-Kaas, O. Kolsrud, Ch. Brinchmann, Oslo 1924, s. 1-41, Pl. I-XXI), nie występują także w krajach Półwyspu Iberyjskiego (M.S. Coll, Iconografía de género. Los sellos de las reinas de Aragón en la Edad Media (siglos XII-XVI), „Emblemata”, 12, 2006, s. 15-52). Na tle pieczęci węgierskich królowych kompozycja pieczęci Jadwigi jest jednak wyjątkowa i bliższa pieczęciom używanym przez królów. Określenie relacji między tą pieczęcią, sigillami jej ojca, matki i siostry, a także pieczęciami królów Polski z dynastii piastowskiej, wymaga jednak dalszych badań.

${ }^{10}$ Z. Piech, Monety, pieczęcie i herby, s. 52. Omawiając pieczęcie Jadwigi w innym miejscu (tenże, Pieczecie herbowe, s. 238-239), badacz ten oparł się na hierarchii zaproponowanej przez I. Sułkowską-Kurasiową, Dokumenty królewskie, 
można na pieczęcie wielkie (z wyobrażeniem trzech herbów: Orła, andegaweńskiej strusiej głowy oraz litewskiej Pogoni; zob. il. 1a) ${ }^{11}$, średnie - z wyobrażeniem dwóch herbów (Orła i herbu Andegawenów w różnej kolejności; zob. il. 1b, c) ${ }^{12}$ i mniejsze z wyobrażeniem jednego herbu (Orła; zob. il. 1d, e) ${ }^{13}$. Do tego ostatniego wariantu należy zapewne również znana jedynie ze słabo zachowanego odcisku pieczęć sygnetowa królowej ${ }^{14}$.

Wyłączywszy okazałą pieczęć majestatową (średnica: $106 \mathrm{~mm}$ ) oraz pieczęć sygnetową (średnica: $17 \mathrm{~mm}$ ), średnice pozostałych oscylowały wokół $30-36 \mathrm{~mm}$. Wszystkie rodzaje pieczęci poświadczone są stosunkowo niewielką liczbą zachowanych odcisków, co utrudnia określenie chronologii ich stosowania. Niewątpliwie do najstarszych należeć będzie pieczęć mniejsza z wyobrażeniem Orła poświadczona odciskiem z 1384 r., a także pieczęć majestatowa. Być może jeszcze przed małżeństwem z Jagiełłą powstała także pierwsza pieczęć herbowa średnia $\mathrm{z}$ wyobrażeniem dwóch tarcz ( $\mathrm{z}$ herbem andegaweńskim i Orłem) podtrzymywanych przez anioła tarczownika, choć poświadczona jest odciskiem już z czasów małżeństwa. Pieczęć herbowa większa (z zespołem trzech herbów) oraz druga pieczęć herbowa średnia (dwuherbowa - z Orłem i herbem andegaweńskim) są zapewne młodsze. Przypuszczenie to, oprócz chronologii zachowanych odcisków ${ }^{15}$, potwierdza również forma inskrypcji napieczętnej wykonanej na obu minuskułą gotycką, a także pojawiający się w ich legendzie tytuł litewski, który mógł zostać do niej wprowadzony po $1387 \mathrm{r}$.

Sfragistyka królowej Jadwigi, ze względu na specyfikę dysponentki, znajdującą odzwierciedlenie w programie heraldycznym jej pieczęci, wymaga osobnego opracowania. Tu postaram się wskazać

s. 43-44, która podzieliła pieczęcie Jadwigi na mniejszą, średnią, małą i sygnetową. Wydaje się jednak, że podział ten, oparty wszak na różnych kryteriach, nie jest najszczęśliwszy.

${ }_{11}$ Średnica: 36 mm; legenda: zob. Aneks, nr 2; oryg.: AN, Archiwum Dzieduszyckich, perg. 11 (1387 r.); Archiwum Lanckorońskich, perg. 15 (1391 r.); Budapeszt, Magyar Nemzeti Leveltar [dalej: MNL Budapeszt], Diplomatikai Leveltar [dalej: DL], sygn. 7910 (1393 r.); literatura: T. Żebrawski, O pieczęciach, s. 41, nr 43, tab. 16; K. Stronczyński, Pobieżny przeglą, s. 64; M. Gumowski, Handbuch, s. 141, nr 120; I. Sułkowska-Kurasiowa, Dokumenty królewskie, s. 44; Album Kielisińskiego, s. 21, nr Ao I 20; Z. Piech, Pieczęcie herbowe, s. 239.

${ }^{12} \mathrm{~W}$ polskiej literaturze dotąd znany był jeden wariant dwuherbowej pieczęci królowej - średnica: $35 \mathrm{~mm}$; legenda: zob. Aneks, nr 3; oryg.: AN, Zbiór luźnych pieczęci, sygn. 9 (b.d.); literatura: T. Żebrawski, O pieczęciach, s. 40, nr 42, tabl. 16; K. Stronczyński, Pobieżny przegląd, s. 64 (podaje on błędną informację o występowaniu w legendzie tej pieczęci tytułu litewskiego. Być może jest to efekt pomyłki z pieczęcią trójherbową bądź też drugą pieczęcią średnią [dwuherbową], zob. niżej); F. Piekosiński, Pieczęcie, s. 288, nr 580; M. Gumowski, M. Haisig, S. Mikucki, Sfragistyka, tabl. V, nr 9; M. Gumowski, Handbuch, s. 21, nr 17; I. Sułkowska-Kurasiowa, Dokumenty królewskie, s. 43; Imagines potestatis, nr III.3.34; Album Kielisińskiego, s. 21, nr Ao I 21; Z. Piech, Pieczęcie herbowe, s. 239. Drugi wariant wzmiankowany był dotąd w opracowaniach węgierskich; zob. O. Barczay, A heraldika kézikönyve müszótárral, Budapest 1897, s. 31, rys. 84. Odcisk tej pieczęci udało się odnaleźć w zbiorach Zakładu Narodowego im. Ossolińskich we Wrocławiu: mierzy on $33 \mathrm{~mm}$ średnicy; legenda: zob. Aneks, nr 4; oryg.: BOss., sygn. 484 (1393 r.); literatura: fotografia oryginału pieczęci ze zbiorów Ossolińskich została opublikowana w: E. Jabłońska, T. Kozielec, I. Jablonskaja, Badania konserwatorskie dokumentów pergaminowych uwierzytelnionych pieczęciami woskowymi wystawionych przez Bolesława Wstydliwego i Jadwige, królowa polska, w: Zabytkowe dokumenty uwierzytelnione pieczęciami. Konserwacja i badania, red. M. Grocholska, K. Korczak, Wrocław 2019, s. 67, il. 2; podobizna odlewu posłużyła zaś jako ilustracja artykułu Z. Piecha dotyczącego klasyfikacji pieczęci herbowych (tenże, Pieczęcie herbowe, s. 237, il. 17). Zapewne do niej odnosi się też odczyt legendy podany przez M. Gumowskiego (Handbuch, s. 40, bez wskazania egzemplarza, ale odmienny od brzmienia doskonale czytelnej legendy z pieczęci dwuherbowej pierwszej), zawierający tytuły ruski i halicki. Jest to jednak odczyt błędny.

${ }_{13}$ Średnica: 29 mm; legenda: zob. Aneks, nr 5; oryg.: AN, Archiwum Sławuckie Sanguszków, sygn. 021 (1389 r.); Kraków, Archiwum Polskiej Prowincji Dominikanów, Zbiór dokumentów pergaminowych Prowincji Polskiej Zakonu Kaznodziejskiego i klasztoru krakowskiego, sygn. 92 (1386 r., jako contrasigillum pieczęci majestatowej); inny egzemplarz przechowywany jest w Archiwum Krakowskiej Kapituły Katedralnej, a informacje o nim podaje KDKK, cz. 2 , nr 329 (1386 r., jako contrasigillum pieczęci majestatowej); literatura: KDMłp., t. 1, wyd. F. Piekosiński, Kraków 1876, nr 321, s. 441; Archiwum książat Lubartowiczów Sanguszków w Stawucie, t. 3: 1432-1534, wyd. B. Gorczak, Lwów 1890, tabl. III, nr LVI; I. Sułkowska-Kurasiowa, Dokumenty królewskie, s. 44; Z. Piech, Monety, pieczęcie i herby, s. 54, przyp. 50; Album Kielisińskiego, s. 20, nr Ao I 19.

14 Średnica: $17 \mathrm{~mm}$; z mocno zniszczonej legendy czytelne są pojedyncze litery; oryg.: AGAD, Zbiór dokumentów papierowych, sygn. 910 (1395 r.), 908 (1397 r.); literatura: I. Sułkowska-Kurasiowa, Dokumenty królewskie, s. 43-44; Pieczęcie królów i królowych Polski, s. 14; Sigilla regum et reginarum, s. 15.

${ }^{15}$ I. Sułkowska-Kurasiowa, Dokumenty królewskie, s. 43-44. 
tylko najważniejsze jej osobliwości. Mimo że pieczęcie dwuherbowe królowej (zarówno pierwsza, jak i druga) należą do kompozycji popularnych w kręgu królowych tego czasu ${ }^{16}$, niosą treści odmienne od prezentowanych na podobnie skomponowanych pieczęciach innych monarszych małżonek. Tak jak zazwyczaj zestawione herby wskazywały na obie strony małżeństwa, tak na pieczęciach Jadwigi schemat ten wykorzystano do prezentacji jej jako samodzielnej władczyni, a to poprzez wskazanie na dynastię, z której pochodziła (herb Andegawenów) oraz terytorium, którym władała (Orzeł). Co ciekawe, jak wskazuje druga pieczęć średnia (dwuherbowa) królowej, komunikat ten nie zmienił się po zawarciu małżeństwa z Jagiełłą, choć przemodelowano sekwencję herbów: Orzeł znalazł się przed herbem dynastycznym. Treści te zostały rozwinięte na pieczęci większej (trójherbowej), na której pierwsze i drugie miejsce zajmują herby Polski oraz znak Andegawenów (strusia głowa), dopiero trzecie zaś Pogoń litewska, wskazująca z jednej strony na używany przez królową tytuł najwyższej księżnej litewskiej ${ }^{17}$, ale też identyfikujący jej małżonka.

Pieczęci kolejnych żon Jagiełły: Anny Cylejskiej oraz Elżbiety Pileckiej (Granowskiej) nie udało się dotąd odnaleźć. Irena Sułkowska-Kurasiowa zna jedynie cztery dokumenty królowej Anny, z tego tylko jeden zachowany w oryginale, za to Grażyna Rutkowska podaje informacje o 12 znanych dokumentach i listach królowej ${ }^{18}$. Pieczęci Anny nie odnalazła też Maria Lukanc, autorka poświęconego jej monograficznego artykułu opartego na kwerendzie przeprowadzonej w wielu środkowoeuropejskich archiwach ${ }^{19}$.

${ }^{16}$ Zob. liczne przykłady zebrane przez K. Mahnič, Srednjeveški ženski pečati iz Arhiva Republike Slovenije, Ljubljana 2006, s. $30-83$.

${ }^{17}$ I. Sułkowska-Kurasiowa, Dokumenty królewskie, s. 39. Tytulaturę używaną w legendach pieczęci podano niżej; zob. Aneks, nr 2, 3, 4

${ }^{18}$ I. Sułkowska-Kurasiowa, Dokumenty królewskie, s. 65; G. Rutkowska, Dwór polskich królowych Anny Cylejskiej i Elżbiety Granowskiej, w: Narodziny Rzeczypospolitej. Studia z dziejów średniowiecza i czasów wczesnonowożytnych, t. 2, red. W. Bukowski, T. Jurek, Kraków 2012, s. 889.

${ }_{19}$ M. Lukanc, Ana Celjska (1. del), „Zgodovinski časopis. Historical Review”, 71, 2017, nr 1-2, s. 30-68; taż; Ana Celjska (2. del), „Zgodovinski časopis. Historical Review”, 71, 2017, nr 3-4, s. 382-427; taż, Anna of Celje (Cilli). In Search of the Overlooked Queen, w: Papers and Proceedings of the Third Medieval Workshop in Rijeka, red. K. Jovanowić, S. Miljan, Rijeka 2018, s. 67-86. Na hipotetyczną rekonstrukcję herbu wyobrażonego na pieczęci Anny pozwalają znane odciski pieczęci innych księżnych bądź królowych pochodzących z rodu hrabiów Cylii. Barbara Cylejska, żona Zygmunta Luksemburczyka, używała dwóch pieczęci, na których skwadrowano starowęgierskie pasy z trzema gwiazdami hrabiów Cylii (połowa XV w.; Megpecsételt történelem: középkori pecsétek Esztergomból, red. A. Hegedűs, Esztergom 2000, s. 73, nr 48; Veszprém megye egyházi élete a középkorban, red. P. Rainer, Veszprém 2009, s. 33; K. Mahnič, Srednjeveški ženski pečati s. 36). Podobnie skomponowano herb na pieczęci Małgorzaty Cylejskiej, żony księcia cieszyńskiego Włodka (1468-1477; M. Kaganiec, Heraldyka, s. 142), Anny Cylejskiej, żony palatyna Węgier Mikołaja II Garai (1405 r.; K. Mahnič, Srednjeveški ženski pečati, s. 35). Wcześniej na pieczęciach hrabianek Cylii umieszczano dwie tarcze herbowe z herbem mężowskim oraz ich znakiem rodowym (zob. tamże, s. 34, 37), a do wzoru tego powróciła Małgorzata, żona Hermanna Montfort-Pfannenberg hrabina Monfort na pieczęci znanej z 1430 r. (tamże, s. 39). Jednym z nielicznych przekazów ukazujących herb rodowy królowej Anny jest fryz heraldyczny znajdujący się w katedrze w Sandomierzu (zob. T. Giergiel, J. Ptak, Fryz heraldyczny odkryty w katedrze sandomierskiej, Rocz. Herald., 10, 2011, s. 17-18, a także chrzcielnica z kościoła św. Stefana w Krakowie, w której programie heraldycznym wykorzystano herby wszystkich żon Władysław Jagiełły, zob. P. Rabiej, Užmirštas paminklas. 1425 m. krikštykla Krokuvos Šv. Stepono bažnyčioje, w: Jogailos ir Vytauto laikai Moksliniu straipsniu rinkinys, skirtas Žalgirio mūšio 600-osioms metinèms, red. Z. Kiaupa i in., Kaunas 2011, s. 175-176, il. 2, 12). Wszystkie one prezentują herb cylejski w formie czteropolowej ze skwadrowanymi pasami i gwiazdami. Przy założeniu, że taki znak królowa położyła na swojej pieczęci, musielibyśmy przyjąć, że znajdowały się na niej przynajmniej dwie tarcze (jedna ze skadrowanym herbem polsko-litewskim, względnie samym Orłem, i druga z czteropolowym herbem cylejskim) bądź też trzy tarcze z wyobrażeniem Orła, Pogoni i herbu cylejskiego. Fakt, że dwuherbowych pieczęci używały tak poprzedniczka Anny - królowa Jadwiga, jak i Zofia Holszańska, a także liczne przedstawicielki dynastii hrabiów cylejskich, pozwala na przyjęcie hipotezy, że i pieczęć królowej Anny należała do pieczęci dwuherbowych. Na marginesie rozważań nad sfragistyką hrabianek cylejskich warto wspomnieć o pieczęci Anny, córki Kazimierza Wielkiego, żony Wilhelma Cylejskiego, a później (od 1393 r.) Ulryka księcia Teck (zob. K. Jasiński, Rodowód Piastów małopolskich i kujawskich, Poznań-Wrocław 2001, s. 199) i matki naszej bohaterki. Jej odcisk zachował się w archiwum w Lublanie przy dokumencie z 16 IX 1394, a więc z czasów jej drugiego małżeństwa. Pieczęć ta mierzy $44 \mathrm{~mm}$. Wyobraża ona w polu pieczęci dwie tarcze: pierwszą z herbem księstwa Teck w Wirtembergii, drugą z piastowskim Orłem w otoczeniu wici roślinnych. Legenda pieczęci, wykonana minuskułą gotycką i ujęta w linię z kropek, brzmi: + S + ANNA + CHVNIG + KASIMIRI + TOCHTER + VON + POLAN + HERTZOGIN + V(on) DEK; zob. K. Mahnič, Srednjeveški ženski pečati, s. 60; M. Lukanc, Anna of Celje (Cilli), s. 74, Fig. 1. 

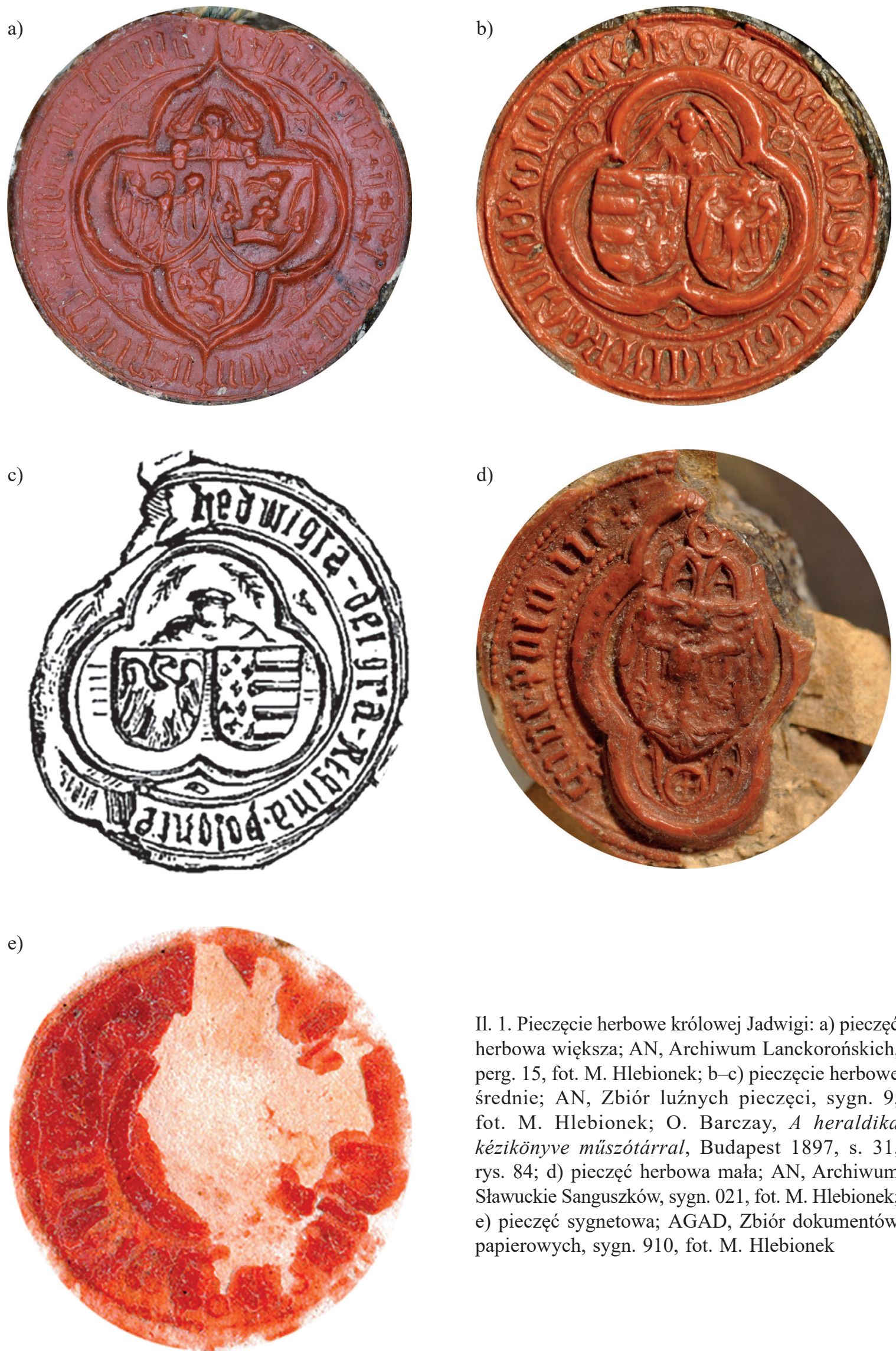

Il. 1. Pieczęcie herbowe królowej Jadwigi: a) pieczęć herbowa większa; AN, Archiwum Lanckorońskich, perg. 15, fot. M. Hlebionek; b-c) pieczęcie herbowe średnie; AN, Zbiór luźnych pieczęci, sygn. 9, fot. M. Hlebionek; O. Barczay, A heraldika kézikönyve müszótárral, Budapest 1897, s. 31, rys. 84; d) pieczęć herbowa mała; AN, Archiwum Sławuckie Sanguszków, sygn. 021, fot. M. Hlebionek; e) pieczęć sygnetowa; AGAD, Zbiór dokumentów papierowych, sygn. 910, fot. M. Hlebionek 
W przypadku Elżbiety Pileckiej (Granowskiej) I. Sułkowska-Kurasiowa wzmiankuje zachowany odcisk jej sigillum, ale pochodzący z czasów sprzed małżeństwa z Jagiełłą ${ }^{20}$. Nie była więc to jeszcze pieczęć, którą można by uznać za pieczęć królowej sensu stricto. Natomiast z okresu małżeństwa z Jagiełłą nie są znane żadne dokumenty Elżbiety ${ }^{21}$.

Dopiero Zofia Holszańska zostawiła po sobie spuściznę sfragistyczną. Znamy dziś dwie używane przez nią pieczęcie. Pierwszą wykonano jeszcze za życia męża ${ }^{22}$. Ma średnicę o długości $25 \mathrm{~mm}$, a wyobraża w polu pieczęci, w perełkowej linii otokowej wewnętrznej podtrzymywane przez anioła tarczownika dwie tarcze: z Orłem i Pogonią, poniżej których znajduje się inicjał S - odwołanie do imienia królowej (zob. il. 2a) ${ }^{23}$. Kolejna pieczęć Zofii w sferze ikonografii odwołuje się do identycznego wzoru. Zmienia się jednak forma pola legendy, które przybiera kształt trzykrotnie zawiniętej wstęgi, a także znika z niej inicjał imienia królowej (zob. il. 2b). Pieczęci tej Zofia używała jako królowa wdowa, a potwierdzają to odciski z lat 1435,1453 [?], 1455 i $1456^{24}$.

Pieczęcie Zofii Holszańskiej, mimo że wielokrotnie publikowane, nie wzbudziły większego zainteresowania badaczy. Być może komponując je, odwołano się do wzorów znanych z pieczęci Jadwigi Andegaweńskiej. Jak już wspomniano, królowa ta również używała pieczęci dwuherbowych, z tym, że prezentowały one polskiego Orła i jej herb dynastyczny. Zastrzec tu jednak trzeba, że kompozycje dwuherbowe spotykamy często na pieczęciach różnych władczyń z przełomu XIV i XV w. oraz pierwszej połowy XV stulecia. Analogie do pieczęci Jadwigi mogą zatem wynikać z akceptacji ogólniejszych, modnych wówczas, wzorów. Podkreślić trzeba, że na pieczęciach Zofii brak odniesień do herbu rodowego, pojawiają się natomiast herby Korony i Litwy, a więc de facto herby państwowe, choć w znajdującej się w legendzie tytulaturze brak tytułu litewskiego. Jest to ewenement, gdyż na pieczęciach królowych odwołujących się do takiej kompozycji znakowi identyfikującemu koronowanego męża (dynastycznemu bądź państwowemu) towarzyszył własny herb małżonki.

Szczególnie interesujące jest umieszczenie w polu pierwszej z pieczęci królowej inicjału jej imienia. Pojawienie się tego unikatowego w sfragistyce królowych polskich tego czasu jednostkowego wyróżnika Z. Piech tłumaczy potrzebą ujednoznacznienia komunikatu zapisanego językiem heraldyki i mocniejszego powiązania jej z osobą królowej. Jak zdaje się dalej sugerować ów badacz, jednym z celów tego zabiegu mogło być odróżnienie pieczęci królowej od pieczęci używanych przez kancelarię królewską, choć - co sam zauważa - kompozycja heraldyczna wyobrażona na pieczęci Zofii istotnie różniła się od kształtu pieczęci kanclerskich i podkanclerskich Jagiełły ${ }^{25}$. Przeciw tej interpretacji przemawia jednak fakt, że inicjał znika z drugiej pieczęci Zofii, choć przecież kształt pieczęci używanych przez kancelarie koronne jej synów nie uległ zmianie ${ }^{26}$. Zastanawia także, dlaczego dla

${ }^{20}$ I. Sułkowska-Kurasiowa, Dokumenty królewskie, s. 65-66.

${ }^{21}$ Tamże, s. 66. Wiemy natomiast, że przy dworze królowej funkcjonował urząd kanclerza, z którym łączy się osobę Andrzeja z Kokorzyna. Źródła pośrednie przynoszą natomiast informacje o prowadzonej przez królową korespondencji; G. Rutkowska, Dwór, s. 897, nr 31. Spostrzeżenie to pozwala na przyjęcie założenia, że Elżbieta Pilecka jako królowa dysponowała własną pieczęcią.

22 B. Czwojdrak, Zofia Holszańska. Studium o dworze i roli królowej w późnośredniowiecznej Polsce, Warszawa 2012 , s. 98.

${ }^{23}$ Legenda: zob. Aneks, nr 6; oryg.: AN, Zbiór luźnych pieczęci, sygn. 16; w materiałach po W. Kielisińskim znajduje się odrys tej pieczęci z informacją, że został on wykonany z dokumentu królowej z 1424 r.; Album Kielisińskiego, s. 27, nr Ao I, 32; literatura: T. Żebrawski, O pieczęciach, s. 48-49, nr 49; M. Gumowski, Handbuch, 1966, s. 152, kat. 178, Taf. X, Nr. 178; Imagines potestatis, III. 3.35, s. 403; B. Czwojdrak, Zofia Holszańska, s. 98; Album Kielisińskiego, s. 27, nr Ao I, 32; Z. Piech, Pieczęcie herbowe, s. 237, il. 18, s. 247.

${ }^{24}$ Średnica: $31 \mathrm{~mm}$; legenda: zob. Aneks, nr 7; oryg.: AGAD, Zbiór dokumentów pergaminowych, sygn. 5042 (1435 r.); 455 (1455 r.); AP Toruń, Akta miasta Torunia, Kat. I, 1370 (1439 r., i ślad odcisku o podobnej średnicy na liście królowej: tamże, 1337 (1453 r.); literatura: K. Stronczyński, Wzory pism dawnych w przerysach wystawione i objaśnione drukowanem ich wyczytaniem, cz. 1, Warszawa 1839, tabl. 18 (odcisk z 1456 r.); Sigilla regum et reginarum, s. 16; B. Czwojdrak, Zofia Holszańska, s. 98.

25 Z. Piech, Monety, pieczęcie i herby, s. 319.

26 Spostrzeżenie to należy opatrzyć zastrzeżeniem, że drugą pieczęć sporządzono dla królowej wdowy. Być może więc zmiana statusu dysponentki wpłynęła w jakiś sposób na formę komunikatu. Choć przecież inicjał imienia miał charakter osobisty: nie wskazywał na status (ten określały herby państwowe), a na osobę dysponentki. Warto też zauważyć, że podobną kompozycję 
doprecyzowania przekazu nie wykorzystano herbu rodowego królowej, co czyniłoby komunikat bardziej jednolitym. Niewykluczone, że wpływ na to miała stabilizująca się dopiero heraldyka książąt Holszańskich ${ }^{27}$, względnie fakt jej niedynastycznego pochodzenia (zob. niżej). Ze względu na stan badań zagadnienia te należy pozostawić otwarte.

Pieczęcie Elżbiety Rakuszanki, żony Kazimierza Jagiellończyka, zrywają z dwuherbową kompozycją heraldyczną wprowadzoną do sfragistyki królowych jeszcze przez Jadwigę, a utrzymaną na pieczęciach Zofii Holszańskiej. Nawiązują natomiast, choć nie bezpośrednio, do wzoru znajdującego się na drugiej pieczęci jej matki, królowej Węgier, Elżbiety Luksemburskiej, żony Albrechta II Habsburga ${ }^{28}$. Do tej pory znana była tylko jedna pieczęć królowej wyobrażająca sześć tarcz z herbami dynastycznymi i państwowymi, z których jedna - ze starowęgierskimi pasami - zajmuje miejsce centralne, a pozostałe ją otaczają (umieszczona od głowicy tarcza z Orłem polskim, z prawej strony tarcza z Lwem czeskim, z lewej z Pogonią, od podstawy z prawej tarcza z austriackim pasem Habsburgów, z lewej zaś kolejna tarcza z Orłem; zob. il. 3b). Nad położoną w górnej części pola pieczęci tarczą z Orłem, wyróżniającą się rozmiarami, znajduje się wyobrażenie podtrzymującego ją anioła tarczownika ${ }^{29}$. Pieczęć ta potwierdzona jest odciskami z lat 1471-1492, choć zapewne była używana przez królową do końca życia. Niedawno udało się odnaleźć egzemplarze wcześniejszego wariantu pieczęci królowej Elżbiety, nieznanego dotąd badaczom, a powstałego i wykorzystywanego w okresie bliskim zawarciu małżeństwa z Kazimierzem Jagiellończykiem. Jest on bliźniaczo podobny do wyżej opisanej pieczęci. W sferze ikonografii różnica między starszym a nowszym wariantem ogranicza się do braku anioła tarczownika

(anioła tarczownika trzymającego tarcze z herbami Korony i Litwy) spotykamy na pieczęci sygnetowej Kazimierza Jagiellończyka; zob. B. Engel, Die mittelalterlichen Siegel der Fürsten, der Geistlichkeit und des polnischen Adels im Thorner Rathsarchive, Danzig 1902, s. 2; Z. Wdowiszewski, Ze studiów nad sfragistyka Kazimierza Jagiellończyka, w: Ksiega pamiątkowa 75-lecia Towarzystwa Naukowego w Toruniu, red. T. Czeżowski, Toruń 1952, s. 235-236; K. Wyczańska, O zaginionych pieczęciach Kazimierza Jagiellończyka, Przegl. Hist., 49, 1958, s. 535-536; M. Gumowski, Handbuch, Taf. 9, nr 170; Z. Piech, Monety, pieczęcie i herby, s. 66; Pieczęcie królów i królowych Polski, s. 25; M. Grulkowski, Kilka uwag o pieczęciach z okresu panowania Kazimierza Jagiellończyka, St. Źródł., 51, 2013, s. 26-27, 28, nr 6; Sigilla regum et reginarum, s. 27; Katalog pieczęci Archiwum Państwowego w Toruniu, z. 1: Pieczęcie królów i królowych polskich do roku 1572, oprac. J. Bonczkowski, D. Chyła, M. Hlebionek, M. Superczyński, Toruń 2020, s. 115, nr 12.

${ }^{27}$ Szerzej na temat heraldyki Holszańskich zob. S. Polechow, M. Butyrski, Pieczęć kniazia Iwana Olgimuntowicza Holszańskiego, w: Inter Regnum et Ducatum. Studia ofiarowane Profesorowi Janowi Tęgowskiemu w siedemdziesiata rocznice urodzin, red. P. Guzowski, M. Liedke, K. Boroda, Białystok, 2018, s. 441-461 (tam wcześniejsza literatura).

${ }^{28}$ K. Sava, Siegel österreichischen Fürstinen im Mittelalter, „Berichte und Mittheilungen des Alterthums-Vereins zu Wien”, 2, 1857, s. 117-118; Die Siegel der deutschen Kaiser und Konige von 751 bis 1806, t. 2, wyd. O. Posse, Dresden 1910, s. 11, Nr 8-10, Taf. 20, Nr 8-10; Veszprém, s. 33, 34; K. Mahnič, Srednjeveški ženski pečati, s. 49, 50; A. Stieldorf, Die Siegel der Herrscherinnen, s. 43, nr 24. Pierwsza z pieczęci Elżbiety Luksemburskiej wyobrażała dwie pochylone ku sobie tarcze herbowe z herbem starowęgierskim i austriackim pasem Habsburgów; zob. Veszprém, s. 33; K. Mahnič, Srednjeveški ženski pečati, s. 49. Podobnie skomponowana była druga, anepigraficzna pieczęć królowej, z dwiema tarczami podtrzymywanymi przez anioła: na pierwszej znajdował się austriacki herb Habsburgów, na drugiej herb andegaweński; A. Stieldorf, Die Siegel der Herrscherinnen, s. 43, nr 24 b. Trzecia pieczęć królowej wyobrażała cztery tarcze ułożone w kompozycję przypominającą wieniec herbowy, na którą składały się starowęgierskie pasy, czeski Lew, niemiecki Orzeł oraz austriacki herb Habsburgów. Dwie dolne tarcze podtrzymywane były przez wspiętego lwa. Powyżej znajdowała się korona otwarta, z której obręczy wychodziły skierowane ku dołowi promienie; zob. Veszprém, s. 34; K. Mahnič, Srednjeveški ženski pečati, s. 50. Według A. Stieldorf w okresie po koronacji na rzymską królową (1440-1442) Elżbieta miała wrócić do pieczęci dwuherbowych, rezygnując z używania pieczęci z czterema herbami; zob. taż, Die Siegel der Herrscherinnen, s. 43, nr 24 (tam wcześniejsza literatura).

29 Średnica: 36 mm; legenda: zob. Aneks, nr 9; oryg.: AGAD, Zbiór dokumentów pergaminowych, sygn. 5135 (1473 r.); AP Gdańsk, Akta miasta Gdańska [dalej: AmG], 300, D/3, 450 (1492 r.); Zakład Narodowy imienia Ossolińskich we Wrocławiu, Dział Numizmatyczny, sygn. S 4559 (jedyny znany mi kompletny egzemplarz pieczęci królowej w zbiorach polskich, odcisk luźny); Drezno, Sächsische Hauptstaatsarchiv, 10005, Hof- und Zentralverwaltung (Wittenberger Archiv), nr loc. 4366/06, Bl. 8 (1471 r.), Bl. 53 (1482 r.); Berlin Dahlem, Geheimes Staatsarchiv Preußischer Kulturbesitz [dalej: GStA PK Berlin], XX H.A., Ordensbriefarchiv, sygn. 17714 (1492 r.); literatura: M. Gumowski, Pieczęcie królowych, s. 184; tenże, Handbuch, s. 40, tabl. X, nr 179, s. 152, il. 179; I. Sułkowska-Kurasiowa, Polska kancelaria, s. 72, 76; Z. Piech, Austriacki herb Habsburgów, s. 572-574; tenże, Pieczęcie herbowe, s. 247; S. Szybkowski, Przyczynki, s. 14-17; Pieczęcie królów i królowych Polski, s. 26; Sigilla regum et reginarum, s. 28. 

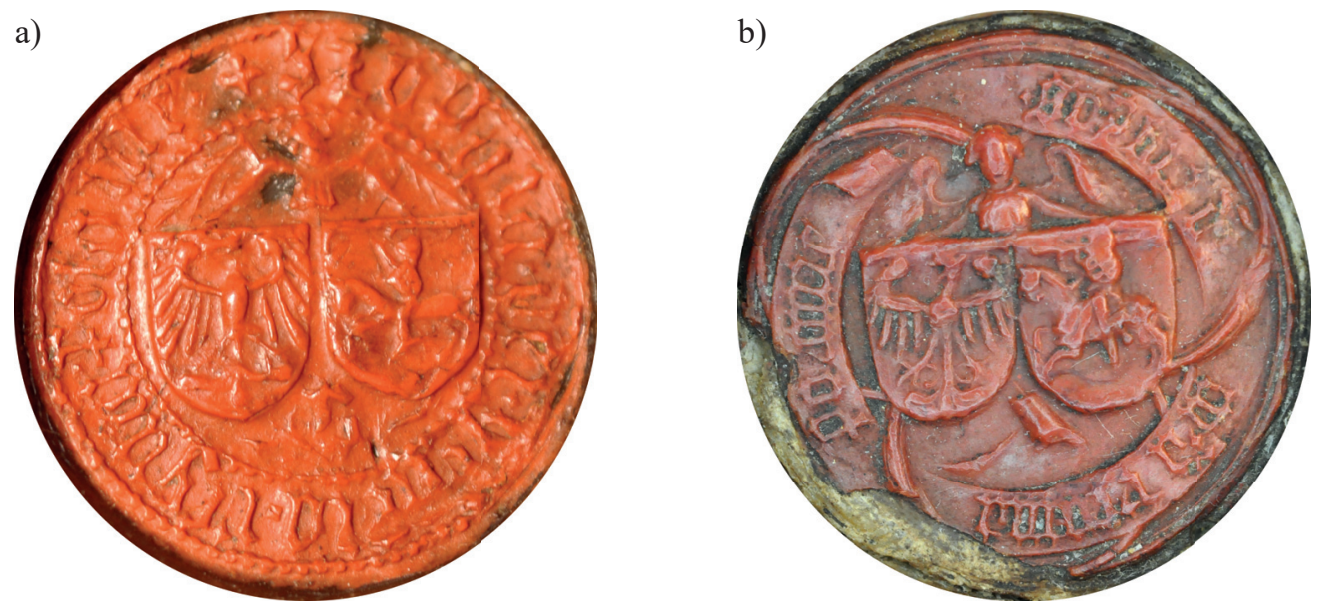

Il. 2. Pieczęcie Zofii Holszańskiej: a) królowej; AN, Zbiór luźnych pieczęci, sygn. 16, fot. M. Hlebionek; b) królowej wdowy; AGAD, Zbiór dokumentów pergaminowych, sygn. 5042, fot. M. Hlebionek
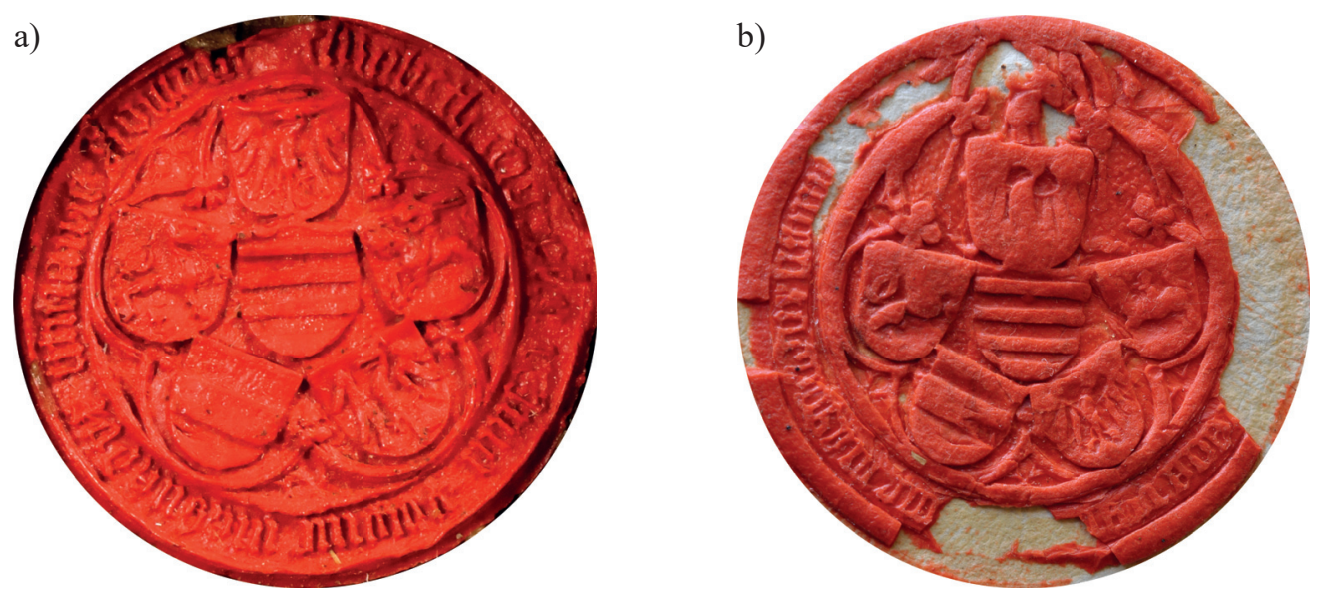

Il. 3. Pieczęcie królowej Elżbiety Rakuszanki: a) znana z lat 1454-1457; Praga, Národní archiv, Archiv České koruny (1158-1935), sygn. 1588; b) znana z lat 1471-1492; AP Gdańsk, Akta miasta Gdańska, 300, D/3, 450, fot. M. Hlebionek

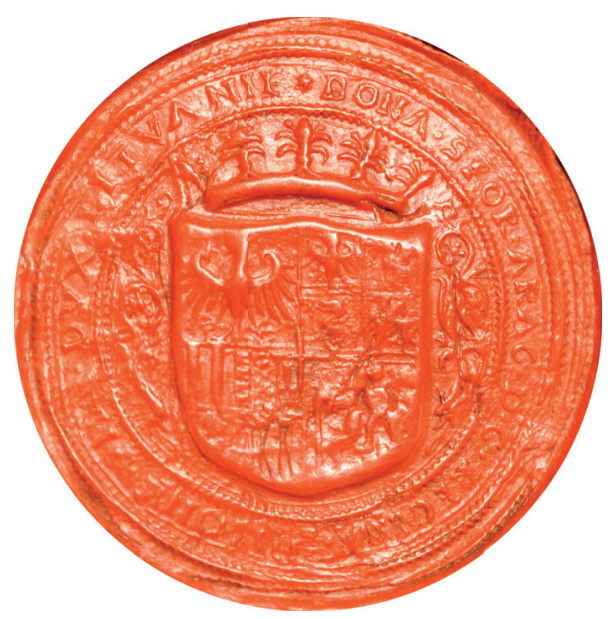

Il. 4. Pieczęć królowej Bony Sforzy; AN, Zbiór luźnych pieczęci, sygn. 32, fot. M. Hlebionek 
podtrzymującego tarczę z Orłem na pieczęci starszej (zob. il. 3a). Drobne odmienności występują też w brzmieniu jej legendy ${ }^{30}$.

Jak już wspomniano, pieczęcie Rakuszanki zawierają rozwinięcie programu heraldycznego z pieczęci matczynej. Herby wykorzystywane przez matkę zostały uzupełnione o znaki ilustrujące tytuły polski i litewski córki. Żeby to zrobić, dokonano zmiany kompozycji „starego zestawu” herbów, kładąc je na obu pieczęciach Rakuszanki w lustrzanym odbiciu w stosunku do tego, co wyobrażała pieczęć matki. Przesunięcie herbu starowęgierskiego do centralnej części pola pozwalało na zyskanie miejsca na nowe, jagiellońskie znaki. Warto też zauważyć, że w legendzie obu pieczęci królowej ponownie pojawia się tytuł litewski, którego brak w inskrypcji pieczęci Zofii Holszańskiej.

Analogie z programem heraldycznym pieczęci Elżbiety Luksemburskiej pozwalają, jak sądzę, na wyjaśnienie znaczenia drugiego $\mathrm{z}$ orłów pojawiających się w napieczętnym zestawie herbów wykorzystanym przez Elżbietę Rakuszankę. Identyfikacja tego godła wzbudziła w polskiej literaturze dyskusję. Z. Piech zaproponował, by widzieć w nim zdwojenie Orła polskiego (tu pełniącego funkcję osobistego znaku Kazimierza Jagiellończyka), który w połączeniu z towarzyszącym mu austriackim pasem wskazywać miał na mariaż dynastii habsburskiej i jagiellońskiej ${ }^{31}$. Z kolei Sobiesław Szybkowski interpretował go jako herb Moraw ${ }^{32}$. Obaj badacze analizowali jednak ten znak w oderwaniu od tradycji rodziny, z której pochodziła Elżbieta. Jak już wspomniano, połączenie Orła i austriackiego pasa Habsburgów znajdujemy także na pieczęci matki Elżbiety Rakuszanki, Elżbiety Luksemburskiej (zob. wyżej, przyp. 28), gdzie związek tych dwóch herbów dodatkowo podkreśla fakt, że obie tarcze są podtrzymywane przez wspiętego lwa. Orzeł z pieczęci Elżbiety Luksemburskiej interpretowany jest jako godło Cesarstwa Niemieckiego, a jego pojawienie się na pieczęci Elżbiety tłumaczone jest tym, że jej ojciec Zygmunt Luksemburski był cesarzem, a mąż Albrecht II królem Niemiec ${ }^{33}$. W tym kontekście właściwsza wydaje się interpretacja drugiego Orła na pieczęci polskiej królowej właśnie jako znaku Królestwa Niemiec. W połączeniu z austriackim herbem Habsburgów wskazywał on na pochodzenie Elżbiety z albertyńskiej linii tej dynastii, a także na jej związki z rodziną cesarską. W ten sposób ekspozycja obu herbów nie tylko mocno podkreślała prestiż królowej, ale też stanowiła ilustrację potencjalnych praw potomstwa Elżbiety i Kazimierza do spadku po albertyńskiej linii Habsburgów ${ }^{34}$. Spostrzeżenie to ma szczególne znaczenie jeżeli zauważymy, że odciski pierwszej pieczęci królowej uwierzytelniają dokumenty, którymi zrzeka się ona wszelkich wynikających z jej pochodzenia roszczeń w Czechach, Austrii i innych krajach niemieckich (zob. wyżej, przyp. 30).

W publikacjach z zakresu sfragistyki można znaleźć informacje o jeszcze jednym wariancie pieczęci Elżbiety, na którym znajdować się miały cztery tarcze i popiersie Najświętszej Maryi Panny lub anioła. Opis jej wprowadzili do obiegu naukowego wydawcy Codicis epistolaris saeculi decimi quinti ${ }^{35}$, skąd zapewne przejął go Marian Gumowski ${ }^{36}$. Przywołane przez wydawców XV-wiecznej korespondencji odciski znajdują się w zasobie Głównego Archiwum Państwowego w Dreźnie ${ }^{37}$. Ich autopsja przekonuje jednak, że są to kolejne (choć mocno uszkodzone) egzemplarze opisanego wyżej nowszego wariantu pieczęci. Zatem pieczęć Elżbiety z czterema tarczami herbowymi prawdopodobnie nie istniała. Zważywszy też na identyczność imienia oraz zbliżoną ikonografię, nie można wykluczyć, że doszło do pomylenia pieczęci matki (Elżbiety Luksemburskiej) z pieczęcią córki (Elżbiety Rakuszanki).

\footnotetext{
30 Średnica: 44 mm; legenda: zob. Aneks nr 8; oryg.: Praga, Národní archiv [dalej: NA Praga], Archiv České koruny, sygn. 1588 (1454 r.), sygn. 1589 (1454 r.). Być może pozostałością po odcisku tej pieczęci jest też ślad o zbliżonej średnicy widoczny na liście królowej do Torunia z 1457 r.; zob. AP Toruń, Akta miasta Torunia, Kat. I, 1744.

31 Z. Piech, Austriacki herb, s. 573.

32 S. Szybkowski, Przyczynki, s. 16-17.

33 Veszprém, s. 34; K. Mahnič, Srednjeveški ženski pečati, s. 50.

${ }^{34}$ S. Titkow, Pieczęć królewicza Kazimierza Kazimierzowica Jagiellończyka z okresu starań o koronę wegierska i jej program polityczny, St. Źródł., 57, 2019, s. 155-156.

35 C. epist. XV, t. 3: 1392-1501, wyd. A. Lewicki, Kraków 1894, s. 153 (komentarz do nr. 126).

${ }^{36}$ M. Gumowski, Handbuch, s. 40.

37 Drezno, Sächsische Hauptstaatsarchiv, 10005, Hof- und Zentralverwaltung (Wittenberger Archiv), nr loc. 4366/06, B1. 8 (1471 r.), Bl. 53 (1482 r.); GStA PK Berlin, XX HA, Ordensbriefarchiv, 17714 (1492 r.).
} 
Żona Aleksandra Jagiellończyka - Helena - ze względu na prawosławne wyznanie nie została koronowana na królową Polski ${ }^{38}$. Mimo tego w tytulaturze odwoływała się do tej godności ${ }^{39}$. Wiemy, że dysponowała ona pieczęcią, o czym świadczą koroboracje wystawianych przez nią samodzielnie dokumentów $^{40}$. Niestety, jak dotąd nie udało się odnaleźć żadnego odcisku uwierzytelniającego je sigillum. Dysponujemy dziś jedynie nieprecyzyjnym opisem egzemplarza pieczęci królowej przywieszonego do dokumentu wydanego przez nią w 1509 r. dla Iwana Sapiehy ${ }^{41}$. Według wydawcy, Maurycego Krupowicza, była to „pieczęć duża”, mocno już uszkodzona. W jej polu znajdowała się nieczytelna w momencie sporządzania opisu tarcza herbowa, a legenda nazywała Helenę królową Polski, wielką księżną litewską, ruską i pruską (zob. Aneks, nr 10) ${ }^{42}$. Nawet te skąpe informacje pozwalają na wyciągnięcie kilku wniosków dotyczących pieczęci królowej. Wprowadzony do inskrypcji napieczętnej tytuł królewski, mimo że Helena nie była królową de iure, wskazuje, że typariusz musiał powstać po dacie koronacji Aleksandra Jagiellończyka (1501). W okresie wcześniejszym (od 1495) zapewne dysponowała pieczęcią oddającą jej wielkoksiążęcy status w legendzie i ikonografii. Wzmianka o tarczy herbowej widocznej w polu opisywanego przez M. Krupowicza egzemplarza pokazuje, że - inaczej niż w kwestiach wyznaniowych w zakresie prezentacji symboli władzy królowa (a zapewne i wielka księżna) przyjęła obyczaje panujące na dworze małżonka. W sferze ikonografii zaowocowało to właśnie odwołaniem do języka heraldyki ${ }^{43}$. Trudno jednoznacznie odpowiedzieć na pytanie, czy brak korony nad tarczą herbową ilustruje realny status Heleny, niekoronowanej przecież, czy też po prostu polskie zwyczaje co do stosowania koron w kompozycjach heraldycznych nie zostały jeszcze ukształtowane ${ }^{44}$. Stan zachowania opisywanego odcisku nie pozwala także na pewne wnioskowanie co do zestawu znaków umieszczonych w tarczy herbowej. W świetle opisanych wyżej praktyk w tym zakresie w grę wchodzą dwie możliwości. Pierwsza opiera się na założeniu, niebędącym chyba hipotezą zbyt daleko idącą, że na obu pieczęciach, wzorem wcześniejszych władczyń polsko-litewskich wywodzących się z domów panujących, połączono znaki męża oraz rodowo-dynastyczne królowej. Problemem bardziej złożonym jest odpowiedź na pytanie, jakie były to znaki. W przypadku hipotetycznej pieczęci wielkoksiążęcej Heleny mogły to być wyobrażenia litewskiej Pogoni i św. Jerzego zabijającego smoka. Tego ostatniego godła używał wówczas jej ojciec Iwan III ${ }^{45}$. Sytuacja ta skomplikowała się w momencie wykonywania królewskiej pieczęci. Należało bowiem znaleźć w tarczy herbowej miejsca na znaki oddające godności męża z jednej strony, z drugiej zaś do systemu symboli władzy wykorzystywanych przez Iwana III ok. 1497 r. wprowadzony został

${ }^{38} \mathrm{Na}$ temat problemów związanych z wyznaniem Heleny zob. G. Rutkowska, Kościół w życiu Heleny moskiewskiej, żony Aleksandra Jagiellończyka, „Średniowiecze Polskie i Powszechne”, 12 (16), 2020, s. 261-299 (tam zebrane wcześniejsze publikacje dotyczące królowej).

39 Przykłady używania tytułu królewskiego przez Helenę zestawia taż, Podróże polskich królowych w XV wieku, w: Samotrzeć, w kompanii czy z orszakiem? Społeczne aspekty podróżowania w średniowieczu i w czasach nowożytnych, red. M. Saczyńska, E. Wółkiewicz, Warszawa 2012, s. 189, przyp. 44; taż, Kościół, s. 298, przyp. 126. Zdaniem K. Pietkiewicza to Aleksander miał wymusić na otoczeniu tytułowanie Heleny królową; zob. tenże, Wielkie Księstwo Litewskie pod rządami Aleksandra Jagiellończyka, Poznań 1995, s. 171.

40 Zob. np. AN, Archiwum Sławuckie Sanguszków, sygn. 118 (1507 r.). Przy dokumencie wystawionym przez królową znajdują się ślady po sznurach napieczętnych. K. Pietkiewicz, a za nim G. Rutkowska, podają informację o 44 znanych dokumentach i listach królowej; zob. K. Pietkiewicz, Wielkie Księstwo Litewskie, s. 39, pkt. 7; G. Rutkowska, Podróże, s. 190, przyp. 45.

${ }^{41}$ Sobranie gosudarstvennyh i častnyh aktov kasaûsihsâ istorii Litvy i soediennyh s nej vladenij (ot 1387 do 1710 goda), red. M. Krupovič, č. 1, Vil'no 1858, nr 27, s. 33. Informację o pieczęci oraz odczyt legendy za powyższym wydawnictwem podaje też G. Rutkowska, Kościół, s. 298, przyp. 126.

${ }^{42} \mathrm{~W}$ legendzie zwraca uwagę sfeminizowana forma tytułu litewskiego (magna ducissa). O ile odczyt legendy podany przez wydawcę jest poprawny, byłby to wyjątkowy przypadek, na pieczęciach poprzedniczek, jak i następczyń konsekwentnie oddawano go bowiem w brzmieniu magna dux, zob. Aneks.

${ }^{43}$ Ówczesne pieczęcie wielkich księżnych moskiewskich nie zawierały wyobrażeń heraldycznych; zob. N.A. Soboleva, Russkie pečati, Moskva 1991, s. 150, nr 21 (pieczęć Zofii Witoldówny z 1451 r.); s. 154, nr 31 (1); nr 32 (2) (pieczęcie Marii Jarosławówny z lat 1453-1482); zob. też tamże, s. 161, nr 47; s. 164, nr 57; s. 170, nr 78; s. 171, nr 80; s. 172, nr 84, gdzie pieczęcie innych żon Rurykowiczów z XV w.

${ }^{44} \mathrm{O}$ wykorzystywaniu koron w heraldyce królowych tego czasu zob. P. Stróżyk, Tablica herbowa, s. 767-770.

${ }^{45}$ N.A. Soboleva, Russkie pečati, s. 157, nr 37 (5), nr 38(6), nr 39 (7), s. 195-209 (zwł. s. 205-208). 
nowy element: wyobrażenie dwugłowego Orła ${ }^{46}$. Drugą możliwością jest odwołanie się przez królową w zakresie heraldyki do godeł wyłącznie mężowskich: najpierw Pogoni, później zaś litewskiej Pogoni i koronnego Orła. Niezależnie od doboru znaków oraz ich kompozycji, konstatacja, że umieszczone one zostały w polu jednej tarczy musi prowadzić do wniosku, że już Helena - jako królowa - wykorzystywała herb wielopolowy. Rozwiązanie to wyprzedzałoby przynajmniej o kilkanaście lat pieczęć królowej Bony, dotąd uważaną za pierwszą z tak skonstruowanym znakiem ${ }^{47}$. Tym samym to właśnie któraś z pieczęci Heleny otwierałaby nowy rozdział w sfragistyce polskich królowych.

Kolejna znana literaturze pieczęć monarchini należała do wspomnianej już drugiej żony Zygmunta I, Bony Sforzy. Z inwentarzy pośmiertnych królowej wiemy, że zostawiła ona po sobie trzy srebrne typariusze pieczęci większych oraz pewną liczbę sygnetów, które również mogły służyć do pieczętowania ${ }^{48}$. Liczba tłoków znajdowałaby uzasadnienie w dużej aktywności królowej. Jednak w obszernym materiale źródłowym, przechowywanym tak w polskich, jak i zagranicznych archiwach, nie udało się odnaleźć odcisków, które wykazywałyby na tyle istotne różnice, które pozwalałby na wyciągnięcie wniosku, że wykonano je różnymi tłokami. Być może wspomniane w pośmiertnym inwentarzu Bony pieczęcie tak dobrze powielały jedno wyobrażenie, że bez precyzyjnych badań ich odróżnienie jest niemożliwe. Jak dotąd nie udało się także odnaleźć śladów po pieczęciach sygnetowych królowejej. Pieczęć Bony wyobrażała w polu zwieńczoną koroną otwartą tarczę herbową podzieloną na cztery pola. W polach pierwszym i czwartym znajdują się odpowiednio godła Polski i Litwy, a w polach drugim i trzecim zespoły godeł dynastycznych królowej (w polu drugim herb Sforzów - skwadrowane Orzeł mediolański i Wąż Viscontich, w polu trzecim herb królestwa Neapolu - aragońskie pręgi skwadrowane z umieszczonymi w polu trójdzielnym w słup godłami dynastycznymi Andegawenów neapolitańskich - pasami, liliami i Krzyżem Jerozolimskim) (zob. il. 4) ${ }^{50}$. Jak słusznie podkreśla Z. Piech, pieczęć królowej Bony należy już do innego etapu dziejowego niż opisane wyżej pieczęcie królowych XV-wiecznych ${ }^{51}$, wyłączywszy hipotetycznie rekonstruowane pieczęcie Heleny Iwanowny.

Dokonany wyżej przegląd sfragistyki polskich królowych XV i początków XVI w. miał na celu jedynie uporządkowanie rozproszonych informacji dotyczących pieczęci tej grupy dysponentów. Nie należy zakładać, że uwzględnia on wszystkie rodzaje pieczęci używane przez żony panujących w Polsce i na Litwie Jagiellonów: stanowi raczej odzwierciedlenie dzisiejszego stanu badań. Jak pokazuje przykład Barbary Zapolyi, pogłębiona kwerenda archiwalna może w sposób istotny zweryfikować naszą wiedzę na ten temat.

46 Tamże, s. 157, nr 38 (6) oraz s. 195-209 (zwł. s. 199-205).

47 Z. Piech, Monety, pieczęcie i herby, s. 84.

48 W liście Zygmunta Augusta z 1558 r. do Lodovica Montia, przebywającego wówczas w Neapolu, czytamy: „Było trzy pieczięci Matki naszey srebrnych y pierścień z szafirem, do tegoż [pieczętowania? - M.H.] używany. Starać się je dostać, a wycisnąwszy na laku dla wiadomości naszey każdą publicznie złamać sztucznie; Szafirową tylko w całości zostawić i wszystkie nam odesłać"; cyt. za: B.M. Vitkauskienė, Złotnictwo wileńskie. Ludzie i dzieła: XV-XVIII w., Warszawa 2006, s. 159 , przyp. 72 .

49 T. Kruszyński, Znaczenie pierścienia $w$ dawnych wiekach i pierścienie królowej Bony, „Sprawozdania z Czynności i Posiedzeń Polskiej Akademii Umiejętności”, 51, 1950, nr 2, s. 37-40. Sygnet królowej Bony z herbem Sforzów, nieznany z oryginalnych odcisków, miał być przechowywany zbiorach Ossolineum; zob. M. Gumowski, Pieczęcie królowych, 185.

50 Średnica: $41 \mathrm{~mm}$; legenda: zob. Aneks, nr 12. Odciski pieczęci królowej znane są z setek egzemplarzy, z których najstarszy znany mi pochodzi z 1521 r. (AP Gdańsk, AmG, 300, D/5B, 2), najpóźniejsze zaś z 1556 r. (Wiedeń, Haus Hof- und Staatsarchiv [dalej: HHStA Wiedeń], Polen I-8, Konv. 3, k. 32v, 40v, 79v, 80v, 120v). Pieczęć Bony była wielokrotnie publikowana. $\mathrm{Z}$ tego względu przywołane tu zostaną wyłącznie pozycje najważniejsze na gruncie sfragistyki: T. Żebrawski, $O$ pieczęciach, s. 62, nr 75, tabl. 21, nr 75; M. Gumowski, Pieczęcie królowych, s. 185; tenże, Handbuch, s. 152, Taf. X, nr 180; Documenta ex archivo Regiomontano, tab. V, nr X; Imagines potestatis, nr III.3.49, s. 107; Pieczęcie królów i królowych Polski, s. 39; Sigilla regum et reginarum, s. 44; Album Kielisińskiego, s. 36, nr AoI, 51. Herby identyfikuje Z. Piech, Monety, pieczęcie i herby, s. 84.

51 Z. Piech, Monety, pieczęcie i herby, s. 84. 


\section{Pieczęć królowej Barbary Zapolyi}

Barbara Zapolya, pierwsza żona Zygmunta Starego, urodziła się w 1496 r. ${ }^{52}$ Pochodziła z Węgier i była córką tamtejszego magnata Stefana Zapolyi oraz księżnej cieszyńskiej Jadwigi53 ${ }^{33}$ Starania o rękę Barbary rozpoczął Zygmunt w 1511 r. Małżeństwo wymagało zgody brata Zygmunta, Władysława II Jagiellończyka, ponieważ Zapolyowie byli jego poddanymi. Rokowania między Zygmuntem a Władysławem zakończyły się 25 I 1511. Dłużej trwały rozmowy z rodziną Zapolyów, które sfinalizowano w grudniu 1511 r., a już 8 lutego roku następnego odbyły się ślub i koronacja Barbary. W momencie ślubu Zygmunt liczył lat 45, Barbara zaś 16. Już w marcu 1513 r. ze związku tego przyszła na świat córka Jadwiga. W tym czasie królowa stale towarzyszyła mężowi w objazdach. Wkrótce po porodzie wyjechała z Zygmuntem na Litwę, córkę pozostawiając pod opieką Elżbiety, siostry Zygmunta. Podczas moskiewskiej wyprawy Zygmunta zakończonej zwycięstwem pod Orszą Barbara pozostawała w Wilnie. Do Korony królewscy małżonkowie powrócili w początkach $1515 \mathrm{r}$. W marcu tego roku Zygmunt pozostawił brzemienną żonę i udał się na zjazd z bratem Władysławem i cesarzem Maksymilianem Habsburgiem. W sierpniu Barbara powiła kolejną córkę Annę (zmarłą w dzieciństwie w 1520 r.). Po porodzie królowa zapadła na zdrowiu. Zmarła już po powrocie Zygmunta z Wiednia 2 X 1515, a jej pogrzeb w kaplicy królewskiej na Wawelu odbył się 18 października tego roku ${ }^{54}$.

Zdaniem badaczy małżeństwo Zygmunta i Barbary było bardzo udane, a postać królowej funkcjonuje w literaturze jako ukochana żona króla. Wyrazem uczuć wiążących Zygmunta ze zmarłą małżonką, oprócz przesyconej nimi korespondencji ${ }^{55}$, miała być przebudowa w duchu renesansowym kaplicy królewskiej, w której, jak już wspomniano, złożono doczesne szczątki królowej ${ }^{56}$.

Z punktu widzenia dalszych rozważań istotne jest zaakcentowanie faktu, że małżeństwo Zygmunta z Barbarą było związkiem niedynastycznym. Związek niedynastyczny, zgodnie z ustaleniami Tadeusza Szulca, rozumiem jako małżeństwo, którego jedna strona nie pochodziła z rodu panującego ${ }^{57}$. Oprócz rozlicznych komplikacji (natury politycznej, prawnej czy społecznej), które związek taki mógł powodować ${ }^{58}$, pojawiał się problem, czy (a jeżeli tak, to w jaki sposób) wpisać w system symboli władzy

52 Dawniejsza literatura przyjmowała, że Barbara urodziła się w 1495 r.; zob. A. Przeździecki, Zygmunt I i Barbara Zapolya, w: tenże, Jagiellonki polskie XVI w. Obrazy rodziny i dworu Zygmunta I i Zygmunta Augusta królów Polski, t. 1, Kraków 1868, s. 9 (tu informacja, że w 1511 r. Barbara miała 17 lat); W. Pociecha, Barbara Zapolya, w: PSB, t. 1, Kraków 1935, s. 293; B. Przybyszewski, Barbara Zapolya, królowa Polski 1512-1515, Łańcut 2000, s. 21; Z. Wdowiszewski, Genealogia Jagiellonów i domu Wazów w Polsce, Kraków 2017, s. 118. Datę tą zweryfikował ostatnio S.A. Sroka, przekonująco wykazując, że Barbara przyszła na świat w pierwszych miesiącach 1496 r.; zob. tenże, Jadwiga Zapolya. Piastówna ślaska na Węgrzech $w$ dobie panowania Jagiellonów, Kraków 2011, s. 27.

${ }^{53} \mathrm{O}$ postaci Jadwigi i jej roli w pertraktacjach małżeńskich zob. S.A. Sroka, Jadwiga Zapolya, s. 11-104 (zwł. s. 45-64), tam wcześniejsza literatura.

${ }^{54}$ Postać królowej Barbary posiada w polskiej historiografii dość obszerną literaturę. Z ważniejszych pozycji, na których oparty został powyższy fragment, trzeba wskazać: A. Przeździecki, Zygmunt I i Barbara Zapolya, s. 42-45; W. Pociecha, Barbara Zapolya, s. 293-294; B. Przybyszewski, Barbara Zapolya, s. 21-80; S.A. Sroka, Jadwiga Zapolya, s. 27-28, 51-53; Z. Wdowiszewski, Genealogia Jagiellonów, s. 117-120. Z węgierskiego punktu widzenia o królowej pisała M. Rekettyés, Adalékok Szapolyai Borbála lengyel királyné trónrajutásának elözményeihez és uralkodásához, „Publicationes Universitatis Miskolcinensis. Sectio Philosophica", 9, 2004, nr 4, s. 119-135.

55 Z. Głombiowska, Zygmunt i Barbara. O listach nieco zapomnianej pary królewskiej, w: Epistolografia w dawnej Rzeczypospolitej, t. 8: Literatura, historia, język, red. P. Borek, M. Olma, M. Piątek, Kraków 2019, s. 197-233.

56 I. Sapetowa, Erotyka plaskorzeźb kaplicy Zygmuntowskiej, w: Sztuka a erotyka. Materiały Sesji Stowarzyszenia Historyków Sztuki, Łódź listopad 1994, red. T. Hrankowska, Warszawa 1995, s. 173; B. Przybyszewski, Barbara Zapolya, s. 80.

57 T. Szulc, Niedynastyczne matżeństwa Jagiellonów i królów elekcyjnych, w: Nil nisi veritas. Księga dedykowana Profesorowi Jackowi Matuszewskiemu, red. M. Głuszak, D. Wiśniewska-Jóźwiak, Łódź 2016, s. 244; tenże, Nierówność stanowa w matżeństwach Jagiellonów i królów elekcyjnych, „Studia Prawno-Ekonomiczne”, 104, 2017, s. 137; zob. też J. Grabowski, Niedynastyczne matżeństwa Piastów mazowieckich, w: Dziedzictwo Piastów mazowieckich. Stan badań i postulaty badawcze, red. J. Grabowski, R. Mroczek, P. Mrozowski, Warszawa 2017, s. 91-112, gdzie omówiono przyczyny zawierania takich związków.

${ }_{58}$ D. Mrówczyńska, Wzorzec społeczny królowej w Polsce XVI wieku, w: Społeczeństwo staropolskie, t. 3, red. A. Wyczański, Warszawa 1983, s. 53-64; T. Szulc, Niedynastyczne matzeństwa Jagiellonów, s. 252-261; tenże, Nierówność stanowa, s. $145-152$. 
rodowe znaki królowej. Zagadnienie to było szczególnie istotne, gdy małżonką panującego stawała się była poddana jego samego lub innego władcy, która będąc dotąd równą statusem szlachcie, jako królowa wyniesiona zostawała ponad nią ${ }^{59}$. Z pieczęci Zofii Holszańskiej (której związek z królem miał również niedynastyczny charakter) zdaje się wynikać, że w czasach Jagiełły nie eksponowano na nich herbu własnego królewskiej małżonki, kładąc tam dwie tarcze: jedną z Orłem, drugą zaś z Pogonią (zob. wyżej), chociaż znak rodowy królowej funkcjonował w innych sferach przestrzeni publicznej, o mniej oficjalnym charakterze ${ }^{60}$.

Barbara była żoną króla tylko przez trzy lata. Nie zachowało się po niej wiele śladów dokumentowych. Dziś znamy przede wszystkim fragmenty korespondencji prowadzonej między królewskimi małżonkami, z której listy Barbary znane są z odpisów w Acta Tomiciana ${ }^{61}$. Również w archiwach węgierskich nie udało się odnaleźć pism wystawianych przez Barbarę. Katalog dokumentów domu Zapolyów nie notuje żadnego ${ }^{62}$. Stąd mianem unikatowego można nazwać zachowany w oryginale list królowej Barbary do władz Gdańska ze wstawiennictwem dla niejakiego Jana Bielawskiego w sprawie pieniędzy, które rada Gdańska była winna jego ojcu za służbę wojskową, na co posiadał odpowiednie dokumenty. List wystawiono w Wilnie 2 stycznia (,feria tercia proxima post festum Circumcisionis Domini”) 1515 r., „commissio propria reginalis M[aiesta]tis" ${ }^{63}$. Przy liście zachował się zamykający go odcisk pieczęci królowej. Jest to okazała pieczęć mierząca obecnie $49 \mathrm{~mm}$ średnicy. W jej polu wyobrażono zwieńczoną koroną otwartą, o pięciu fleuronach, renesansową tarczę herbową z trójłukową głowicą i lekko wciętymi skrajami. Z obu jej stron znajdują się ornamenty roślinne. Tarcza została podzielona na cztery pola. W polu pierwszym widoczny jest orzeł (zapewne ukoronowany), w polu drugim pół wspiętego wilka na trójwzgórzu i powyżej przed nim półksiężyc, pole trzecie i czwarte na awersie kustodii są właściwie nieczytelne (zob. il. 5a). Jednak na jej rewersie zachowały się ślady po odcisku woskowym pozwalające z pewnością odtworzyć godło umieszczone w polu czwartym, którym był orzeł, oraz zidentyfikować fragmenty godła znajdującego się w polu trzecim jako przedstawienie wspiętego kopytnego zwierzęcia (zob. il. 5b). Niestety, zniszczenia lewej strony są tak duże, że nie można jednoznacznie wskazać, czy na grzbiecie zwierzęcia znajdował się jeździec bądź jakiś inny element. Inskrypcja napieczętna na licu kustodii jest niemożliwa do odczytania. Na częściowy jej odczyt pozwala jednak wspomniany już ślad odcisku znajdujący się na rewersie papierowej osłony. Znajdujące się tam litery składają się w napis: [...]A $\cdot \mathrm{D} \cdot \mathrm{G} \cdot \mathrm{REGINA} \cdot \mathrm{POLONIE} \cdot \mathrm{MAGNA} \cdot \mathrm{DVX} \cdot[\ldots]$. Uzupełnienie braków inskrypcji jest możliwe dzięki intytulacji listu, przy którym zachował się interesujący nas zabytek ${ }^{64}$. Po rekonstrukcji i rozwiązaniu abrewiacji legenda brzmi: [BARBAR]A $\cdot \mathrm{D}($ ei $) \cdot \mathrm{G}($ racia $)$ $\cdot$ REGINA · POLONIE $\cdot$ MAGNA $\cdot$ DVX · [LITHVANIE ETC]. Legenda, podobnie jak na pieczęci

${ }^{59}$ W kontekście małżeństwa Barbary Radziwiłłówny z Zygmuntem Augustem zob. D. Mrówczyńska, Wzorzec społeczny, s. 60-61. O skomplikowanych relacjach Jagiellonów z możnowładztwem pisał ostatnio P. Węcowski, Jagiellonowie wobec możnowładztwa w XIV-XVI wieku, w: Europa Jagellonica 1386-1572: sztuka, kultura i polityka w Europie Środkowej za panowania Jagiellonów. Materiały sesji zorganizowanej przez Zamek Królewski w Warszawie - Muzeum i Instytut Historyczny Uniwersytetu Warszawskiego, red. P. Mrozowski, P. Tyszka, P. Węcowski, Warszawa 2015, s. 83-97.

${ }^{60}$ P. Rabiej, Užmirštas paminklas, s. 174-175. P. Stróżyk zwrócił uwagę, że w zależności od przewidywanej sfery funkcjonowania znaku królowej zmieniała się jego kompozycja i zestaw prezentowanych w nim godeł; zob. tenże, Tablica herbowa, s. 772.

${ }^{61}$ Acta Tomiciana, t. 3, wyd. T. Działyński, Kórnik 1852, s. 160, 341-342, 347, 355-356, 364-370, 372, 384-385, 388, 390-392, 396-398, 413-414, 418. Ostatnio zebrał je i opublikował w przekładzie na język polski B. Przybyszewski, zob. tenże, Barbara Zapolya, s. 83-179. Korespondencję tę analizuje Z. Głombiowska, Zygmunt i Barbara, s. 197-233.

62 Zob. A Szapolyai család oklevéltára, t. 1: Levelek és oklevelek (1458-1526), wyd. T. Neumann, Budapest, 2012, ss. 592. Informacje o korespondencji prowadzonej przez Barbarę z rodziną podaje A. Krzycki w liście do Krzysztofa Szydłowieckiego opisującym zwycięstwo pod Wiśniowcem; Acta Tomiciana, t. 2, wyd. T. Działyński, Kórnik 1852, nr LXIV, s. 73. Fragment tego listu we własnym przekładzie na język polski publikuje B. Przybyszewski, Barbara Zapolya, s. 43. W tym miejscu warto wspomnieć o liście wstawienniczym królowej Barbary skierowanym do księżnej mazowieckiej Anny Radziwiłłówny, wdowy po Konradzie III, w sprawie Stanisława Krzywonosa z Wąsów, wzmiankowanym w dokumencie tejże księżnej z marca 1514 r., zezwalającym temuż Stanisławowi na czasowe użytkowanie wymienionych dóbr książęcych; zob. MK, 340, k. 47v-48. Za informację o tym źródle dziękuję Pani Doktor Marcie Piber-Zbieranowskiej.

${ }^{63}$ AP Gdańsk, AmG, 300, D/5, 791.

${ }^{64}$ Intytulacja dokumentu brzmi: „Barbara dei gracia regina Polonie, magna dux Lihuanie, Russie Prussieq[ue], etc. domina”. 
podkanclerskiej Zygmunta, została wykonana kapitałą protorenesansową. Podobieństw między owymi dwoma pieczęciami jest zresztą więcej. Zbliża je także sposób plastycznego ukazania podziałów tarczy herbowej poprzez umieszczenie poszczególnych pól na różnych płaszczyznach (pola pierwsze i czwarte były nieco głębiej rytowane niż pola drugie i trzecie), a także rozmiary. Jak już wspomniano, odcisk mierzy dziś $49 \mathrm{~mm}$ średnicy (średnica pieczęci podkanclerskiej Zygmunta to $46 \mathrm{~mm}$ ). Zważywszy na stan zachowania pieczęci oraz możliwość pewnego rozpłaszczenia odcisku, nie można wykluczyć, że jej średnica pierwotnie odpowiadała średnicy pieczęci podkanclerskiej. Jednocześnie pieczęć Barbary wymiarami przewyższa niemal wszystkie znane pieczęcie swych poprzedniczek, z wyłączeniem pieczęci majestatowej królowej Jadwigi.

\section{Herb królowej Barbary Zapolyi}

W sferze ikonografii sigillum Barbary Zapolyi należy jednak już do innej epoki niż pieczęcie jej poprzedniczek. Z pola pieczęci znika anioł tarczownik, będący cechą charakterystyczną pieczęci królowych od czasów Jadwigi (wyłączywszy pierwszą pieczęć Elżbiety Rakuszanki oraz pieczęć Heleny Iwanowny), a nad tarczą pojawia się korona otwarta, być może na wzór pieczęci królowych czesko-węgierskich (zob. niżej). Insygnium to w sposób bardziej wyrazisty niż postać anioła wskazywało na godność dysponentki ${ }^{65}$. Odtąd kolejne polskie królowe będą zdobiły umieszczony na pieczęci herb bądź herby wyobrażeniem korony: najpierw otwartej, a od czasów Konstancji, żony Zygmunta III, zamkniętej ${ }^{66}$. Wreszcie pojawiająca się w polu tarcza wielopolowa odpowiada zwyczajom charakterystycznym dla nowożytnej sfragistyki monarszej w ogóle ${ }^{67}$, a pieczęć Barbary stanowi pierwszy zachowany i pewny przykład zastosowania takiego rozwiązania w sfragistyce polskich królowych. Rozwiązaniem

${ }^{65}$ W końcu XV w. anioł regularnie pojawiał się na pieczęciach synów Kazimierza Jagiellończyka; zob. Z. Piech, Monety, pieczęcie i herby, s. 85-89; M. Hlebionek, Pieczęcie polskich królewiczów, „Sfragìstičnij ŝorì̌nik”, 4, 2013, s. 161-165; S. Szybkowski, Nieznana pieczęć królewicza Kazimierza z 1482 roku, Rocz. Hist., 81, 2015, s. 189-197; Z. Piech, Pieczęcie herbowe, s. 250-251; S. Titkow, Pieczęć królewicza, s. 141-157, ale też w sfragistyce książąt mazowieckich; zob. S.K. Kuczyński, Pieczęcie książąt mazowieckich, Warszawa 1978, s. 368, nr 60; s. 382, nr 71; s. 383, nr 72; s. 385 , nr 74.

${ }^{66}$ Pieczęć Konstancji zob. Pieczęcie królów i królowych Polski, s. 82; Sigilla regum et reginarum, s. 95. Korona nie pojawia się w ogóle na pieczęciach Elżbiety Habsburżanki, pierwszej żony Zygmunta Augusta. Obecnie znamy dwie jej pieczęcie: większą (średnica $35 \mathrm{~mm}$, legenda: zob. Aneks, nr 13), wyobrażającą skwadrowaną Pogoń i austriacki herb Habsburgów (M. Gumowski, Handbuch, s. 152, Taf. X, nr 181; Z. Piech Monety, pieczęcie $i$ herby, s. 84; Album Kielisińskiego, s. 39, nr Ao I 57), i mniejszą (średnica $24 \mathrm{~mm}$, anepigraficzna), tylko z herbem habsburskim, także bez korony (Documenta ex archivo Regiomontano, tab. V, nr XI). Druga (mniejsza) jest poświadczona w użyciu wcześniej, już w 1544 r. (zob. np. GStA PK Berlin, Herzogliches Briefarchiv [dalej: HBA], B1, k. 300, nr 283, 287, 293, 295) i być może wykonana została jeszcze przed ślubem, na co wskazywałoby uwzględnienie na niej tylko własnego dynastycznego herbu królowej. Pierwsza pieczęć (większa) znana mi jest tylko z dwóch odcisków, obu z 1545 r.; HHStA Wiedeń, Polen I-5, Konv. 2, k. 34 oraz BCzart., perg. nr 862. Brak korony na tej pieczęci Elżbiety przekonująco wyjaśnił Z. Piech, Monety, pieczęcie i herby, s. 84, wskazując, że kształt wyobrażenia odpowiadał pozycji królowej, której mąż sprawował realną władzę jedynie w Wielkim Księstwie Litewskim. Korona nie pojawia się także na pierwszej pieczęci Barbary Radziwiłłówny, którą wykonano po zawarciu małżeństwa, ale jeszcze przed jej koronacją (oryg.: AGAD, Archiwum warszawskie Radziwiłłów, dz. III, sygn. 29, k. 45, 47 [1549, 1550 r.]; literatura: E. Diehl, Uzupetnienie, szp. 111, rys. 6; M. Gumowski, Handbuch, s. 152, Taf. X, nr 182; Z. Piech, Monety, pieczęcie i herby, s. 84). Na drugiej pieczęci Barbary, z okresu po koronacji, korona (otwarta) jednak już występuje (oryg.: np. GStA PK Berlin, HBA, B1, k. 307, nr 511 [1551]; literatura Documenta ex archivo Regiomontano, tab. V, nr XII), zob. il. 7. Korona otwarta wieńczy tarczę herbową także na obu znanych pieczęciach królowej Katarzyny Habsburżanki, trzeciej żony Zygmunta Augusta (pieczęć większa: znana z lat 1553 [AP Gdańsk, AmG, 300, D/5B, 447] 1568 [HHStA Wiedeń, Polen I-13, Konv. 8c, k. 148 v], średnica: 45 mm, wyobraża w polu pieczęci ukoronowaną pięciopolową tarczę ze skwadrowanymi herbami Polski i Litwy w tarczy głównej oraz austriackim pasem Habsburgów w tarczy sercowej, legenda: zob. Aneks, nr 16; literatura: E. Diehl, Uzupetnienie, szp. 111, rys. 7; M. Gumowski, Handbuch, s. 15, nr 13, s. 40; Documenta ex archivo Regiomontano, tab. VI, nr XIII; Z. Piech, Monety, pieczęcie i herby, s. 84; Album Kielisińskiego, s. 39, nr Ao I, 56. Pieczęć mniejsza: znana z lat 1559 [HHStA Wiedeń, Polen I-9, Konv. 6, k. 68 v] - 1572 [GStA PK Berlin, HBA, B1, k. 301, nr 305a], średnica: 28 mm, wyobrażenie powtarza schemat z pieczęci większej, legenda: zob. Aneks, nr 17]; literatura: Documenta ex archivo Regiomontano, tab. VI, nr XIV).

${ }^{67}$ Z. Piech, Pieczęcie herbowe, s. 247. 
tym sigillum Barbary wyprzedza przynajmniej o trzy lata pieczęć królowej Bony, dotąd uważaną za pierwszą z takim herbem. Tym samym to ona otwiera nowy rozdział w sfragistyce polskich królowych.

Oficjalny herb Barbary Zapolyi używany przez nią w okresie małżeństwa z Zygmuntem nie był dotąd znany. Nie zachowały się bowiem ani żadne jego przekazy graficzne, ani też opisy. Do wyjątków należy drzeworytowe wyobrażenie herbu królowej z 1515 r. zdobiące Ad Sigismundum Poloniae regem post partam de Moschis victoriam carmen Andrzeja Krzyckiego, opublikowane w oficynie Jana Hallera ${ }^{68}$. Wydaje się jednak, że prezentowało ono jedynie osobisty znak królowej i miało mniej oficjalny charakter, co postaram się niżej uzasadnić. Nieznająca go Éva Gyulai, analizując występowanie herbu Zapolyów (tak Barbary, jak i Jana Zygmunta) w kontekście polskich znaków dynastycznych, opierała się na wierszach Andrzeja Krzyckiego czy Klemensa Janickiego ${ }^{69}$.

Kluczowe dla zrozumienia herbu umieszczonego na pieczęci królowej jest godło znajdujące się w trzecim polu tarczy herbowej. Niestety, jest ono niemal nieczytelne. Układ pozostałych elementów, a szczególnie umieszczenie w polu pierwszym i czwartym wyobrażenia Orła, zdaje się sugerować, że w herbie królowej połączono polskiego Orła, używanego też jako godło dynastyczne przez Jagiellonów ${ }^{70}$, z jej znakami rodowymi.

Herb rodziny Zapolyów ukształtował się stosunkowo późno, bowiem dopiero w drugiej połowie XV w. Pierwszy jego wizerunek znajduje się na pieczęci Emeryka Zapolyi z 1462 r., a nieco później pojawia się na pieczęciach jego braci: Mikołaja, biskupa siedmiogrodzkiego, oraz ojca Barbary, Stefana. Wyobrażał on pół wspiętego wilka na trójwzgórzu pomiędzy księżycem z prawej i gwiazdą (słońcem) z lewej strony. Według Tibora Neumanna wcześniej tak Emeryk, jak i Stefan mieli pieczętować się herbem wyobrażającym w tarczy koło wozowe bez jednego dzwonu, z którego wyrasta zbrojne ramię z otłuczonym mieczem ${ }^{71}$. W latach 80 . XV stulecia, wraz ze wzrostem znaczenia rodziny, wyobrażający wilka herb Zapolyów uzupełniono o wizerunek wspiętego jednorożca ${ }^{72}$. Nie wchodząc w dyskusję na temat genezy i znaczenia jednorożca, wystarczy stwierdzić, że godło to zostało zaakceptowane przez rodzinę i włączone do herbu jako jego stały element. Herby z połączonym w różnych konfiguracjach wyobrażeniem wilka i jednorożca były używane przez późniejsze pokolenia Zapolyów, w tym na pieczęciach króla Jana I, króla elekta węgierskiego Jana Zygmunta Zapolyi, a także w sfragistyce królowej Izabeli Jagiellonki ${ }^{73}$.

W kontekście rekonstrukcji herbu umieszczonego na pieczęci Barbary warto przywołać epigramat Andrzeja Krzyckiego, kanclerza królowej, Na herb królowej Barbary połaczony z Ortem. Utwór ten datowany jest na 1512 r., a więc okres bliski zawarciu małżeństwa Barbary z Zygmuntem. Krzycki odwołuje się w nim do tradycyjnego herbu Zapolyów - wilka, który od Orła miał otrzymać insygnia królewskie. Krzycki zdaje się w poetycki sposób opisywać to, co sugeruje układ czytelnych godeł umieszczonych w tarczy herbowej znajdującej się w polu pieczęci: połączenie jagiellońskiego Orła z herbem rodowym Zapolyów ${ }^{74}$. Podobne zestawienie godeł zawiera wspomniany wyżej drzeworyt prezentujący

${ }^{68}$ Polonia typographica saeculi sedecimi. Zbiór podobizn zasobu drukarskiego tłoczni polskich XVI stulecia, z. 4, oprac. H. Kapełuś, Wrocław-Warszawa 1962, tabl. 127.

${ }^{69}$ É. Gyulai, Carmina in arma Zapolyana. Címversek Szapolyai Borbála lengyel királyné (1512) és Szapolyai János Zsigmond választott király (1567) címeréröl, „Publicationes Universitatis Miskolciensis. Sectio Philosophica”, 9, 2004, nr 4, s. 64-65.

70 Z. Piech, Monety, pieczęcie i herby, s. 199-227.

71 T. Neumann, A Szapolyai család legrégebbi címere, „Turul”, 84, 2011, 4, s. 125; tenże, A Szapolyaiak címerhasználatáról. Válasz Gyöngyössy Márton irására, „Turul”, 86, 2013, 2, s. 70.

${ }^{72}$ Na podstawie wyobrażeń jednorożców flankujących herby Rzeczypospolitej P. Stróżyk powiązał dynastyczno-państwowe elementy kompozycji heraldycznej umieszczonej na tablicy fundacyjnej kaplicy Trzech Hostii w kościele Bożego Ciała w Poznaniu z osobą Barbary Zapolyi; zob. tenże, Tablica herbowa, s. 777-785.

${ }^{73} \mathrm{Na}$ temat herbu Zapolyów zob. wyżej, przyp. 71; É. Gyulai, A Szapolyai-címer változatai a 15-16. században, „Publicationes Universitatis Miskolciensis. Sectio Philosophica", 13, 2008, z. 3, 125-163; taż, Carmina in arma Zapolyana, s. 61-81; M. Gyöngyössy, Egyszarvú vagy farkas? Még egyszer a Szapolyaiak címerhasználatához, „Turul”, 86, 2013, 2, s. 66-71, tam wcześniejsza literatura. W języku polskim dzieje herbu Zapolyów streszcza S.A. Sroka, Jadwiga Zapolya, s. 30-31; zob. też P. Stróżyk, Tablica herbowa, s. 776-777.

${ }^{74}$ A. Krzycki, In insignia reginae Barbarae aquilae coniuncta, w: Andrae Cricii carmina, wyd. C. Morawski, Kraków 1888, s. 28, nr VI; zob. też tamże, s. 29, nr VII; B. Przybyszewski, Barbara Zapolya, s. 24-25 (w tłum. autora). 
herb Barbary, w tę stronę idzie również wizja herbu królowej zaproponowana przez É. Gyulai, oparta właśnie na wierszu Krzyckiego ${ }^{75}$. Obraz ten należałoby jednak skorygować na podstawie zarysu godła znajdującego się w polu trzecim tarczy herbowej prezentowanej na interesującej nas pieczęci. Herb Zapolyów w takim układzie przybrałby na pieczęci polskiej królowej wersję dostojniejszą, złożoną z dwóch godeł: wilka (pole drugie) oraz jednorożca (pole trzecie).

Rekonstrukcja ta budzi jednak poważne wątpliwości, jeżeli przyjrzymy się wymowie tak zbudowanego znaku. Wśród godeł znajdujących się na pieczęci Barbary nie pojawiałaby się bowiem litewska Pogoń, godło drugiego członu Rzeczypospolitej. Pominięcie go w programie heraldycznym pieczęci i zastąpienie jednym z herbów rodowych królowej - przecież niedynastycznych - stanowiłoby ewenement. Tym bardziej że zarówno w intytulacji listu do Gdańska, przy którym zachował się interesujący nas odcisk, jak i w legendzie samej pieczęci znajduje się tytuł litewski. Sądzę więc, że podstawy dla rekonstrukcji i interpretacji układu godeł w herbie królowej Barbary trzeba szukać gdzie indziej.

Uwagę należy moim zdaniem skierować w stronę pieczęci używanych współcześnie przez królowe czeskie i węgierskie. Ich kształt znany był niewątpliwie tak Zapolyom, jako poddanym i bliskim współpracownikom Macieja Korwina, a później Władysława Jagiellończyka, jak i królowi Zygmuntowi, który młodość spędził pod opieką brata. Od czasów Beatrycze Aragońskiej, może za wyjątkiem Barbary Hohenzollern, której znana mi pieczęć prezentowała inny wzór ${ }^{76}$, królowe węgierskie kładły na swe pieczęcie ukoronowaną tarczę herbową dwudzielną w słup. W prawej pobocznicy znajdowały się państwowe i dynastyczne godła królewskiego małżonka, w lewej zaś godła przynależne królowej. Tak skomponowane herby znajdujemy na kolejnych większych pieczęciach Beatrycze Aragońskiej (zarówno jako żony Macieja Korwina ${ }^{77}$, jak i Władysława II) ${ }^{78}$, Anny de Foix (trzeciej żony Władysława II; zob. il. 6) ${ }^{79}$, Marii z Habsburgów (żony Ludwika Jagiellończyka) ${ }^{80}$ czy Anny Jagiellonki (żony Ferdynanda I) ${ }^{81}$.

75 É. Gyulai, Carmina in arma Zapolyana, s. 64 66. Analizując epigramat, badaczka ta zauważa, że nie wspomina on o używanym przez Zapolyów jednorożcu.

${ }^{76}$ GStA PK Berlin, VII HA, Märkische Ortschaften, Crossen, nr 19 (1482 r.).

${ }_{77}$ Pierwsza pieczęć Beatrycze: L. Szinvay, Beatrix és Izabella királynék pecsétei, „Turul”, 1, 1883, s. 68; C. Csapodi, Beatrix Kiralyine Konyvtara, Budapest 1964, s. 5-6, s. 12, il. 4; Z. Bándi, A Magyar Országos Levéltár Mátyás-kori pecsétkiállitásának katalógusa (1990. április 6.-október 6), „Levéltári Közlemények”, 62, 1991, s. 74, nr 15; Veszprém, s. 34.

${ }^{78}$ Druga pieczęć Beatrycze: oryg.: HHStA Wiedeń, Ungarische Akten, 342, fol. 11 (1489 r.), fol. 15 (1490 r.); MNL Budapeszt, DL, sygn. 71022 (1490 r.), 46400 (1497 r.); DL 102659 (1495 r.); trzecia pieczęć: oryg.: HHStA Wiedeń, Ungarische Akten, 342, fol. 24 (1494 r.).

${ }^{79}$ Królowa używała dwóch pieczęci, które różnią się umieszczeniem (bądź nie) w polu pieczęci inicjałów pary królewskiej [W//A na pieczęci pierwszej]; zob. pierwsza pieczęć: oryg.: NA Praga, Maltézští rytíŕi - české velkopřevorství (1085-1875), sygn. 2551 (1503 r.); MNL Budapeszt, DL, sygn. 84585 (1503 r.); literatura: V. Fraknói, Werböczi István 1458-1541, Budapest 1899, s. 109, fig. 41. Druga pieczęć: oryg.: MNL Budapeszt, DL, sygn. 46683 (1504 r.); literatura: C. Csapodi, Beatrix, s. 6, s. 13, il. 6; Z. Bándi, A Magyar Országos Levéltár Jagelló-kori pecsétkiállitásának katalógusa (1991. szeptember 20. - 1992 június 30), „Levéltári Közlemények”, 64, 1993, s. 113, nr 9; Veszprém, s. 34.

${ }^{80}$ Znamy dziś pięć rodzajów pieczęci (w tym sygnet) używanych przez Marię, a odwołujących się do wspomnianej konwencji, pieczęć pierwsza: oryg.: NA Praga, Maltézští rytî́i - české velkopřevorství (1085-1875), sygn. 143 (1522 r.). Pieczęć druga znana jest z wielu egzemplarzy, z których najstarszy pochodzi z 1521 r. (oryg.: HHStA Wiedeń, Ungarische Akten 345, Konv. 8-12, fol. 23), najmłodszy zaś z 1548 r. (oryg.: HHStA Wiedeń, Ungarische Akten 344, fol. 165v, fol. 167, fol. 179v; Ungarische Akten 345, Konv. 1, fol. 78v); pieczęć trzecią poświadczają dwa egzemplarze, oba z 1554 r. (oryg.: Wolfenbüttel, Niedersächsische Landesarchiv, 1 Alt 1a, fb 1, nr 18, k. 4v, 35v); pieczęć czwarta znana jest z kilku odcisków z lat 1543-1544 (oryg.: HHStA Wiedeń, Belgien PA, 38, Konv. 4, k. 107v; Ungarische Akten 344, k. 67v; Belgien PA, 42, Konv. 4, k. 113 v; Belgien PA 40, Konv. 1, k. 101v, 123v); pieczęć piąta (sygnetowa) pojawia się w latach 1543-1545 (oryg.: HHStA Wiedeń, Belgien PA 38, Konv. 4, k. 26v,102v, 128v, 139v, 144v, 145v; Belgien PA 42, Konv. 1, k. 61v; Konv. 4, k. 143v, 155v, 156v, 157v). Literatura wzmiankuje zazwyczaj najczęściej występującą drugą pieczęć królowej; zob. C. Csapodi, Beatrix, s. 6; Z. Bándi, A Magyar Országos Levéltár Jagelló-kori pecsétkiállitásának katalógusa, s. 114, nr 12; Veszprém, s. 34.

${ }^{81}$ Znamy dziś siedem pieczęci Anny. Interesująca nas kompozycja herbów występuje na jednym tylko wariancie poświadczonym odciskami z lat 1526-1528, a została umieszczona na charakterystycznej romboidalnej tarczy, rzadko spotykanej w heraldyce środkowoeuropejskiej. Może to wskazywać, że była używana przez królową jeszcze przed uzyskaniem przez nią i jej męża tronu węgierskiego; zob. HHStA Wiedeń, Familienakten 8, Konv. 8-10, fol. 31 (1526 r.), fol. 48 (1528 r.). Koroboracje dokumentów, przy których została odciśnięta, nazywają ją pieczęcią sekretną. 
Odejście od tego wzoru nastąpiło dopiero na pieczęci Izabeli Jagiellonki, żony króla Jana Zapolyi ${ }^{82}$. W latach późniejszych model ten został całkowicie zarzucony ${ }^{83}$.

Na możliwość zastosowania analogicznego rozwiązania na pieczęci Barbary, oprócz wspomnianej już znajomości zwyczajów obowiązujących na dworze węgierskim, wskazuje także korona otwarta umieszczona nad tarczą, w sfragistyce królowych polskich dotąd niewystępująca, jednak od czasów Elżbiety Luksemburskiej konsekwentnie pojawiająca się na pieczęciach królowych węgierskich ${ }^{84}$. Dodatkową przesłanką jest wyraźne zaznaczenie pionowego podziału tarczy, mocno na pieczęci uwypuklonego, dzięki wykorzystaniu linii grubszej niż ta, która wyznacza podział poziomy. W takim układzie w prawej pobocznicy tarczy powinniśmy oczekiwać godeł wskazujących na małżonka, w lewej zaś znaków królowej. Jak już wspomniano, kluczowa dla weryfikacji tej hipotezy jest identyfikacja szczątkowo zachowanego znaku znajdującego się w polu trzecim, ale też interpretacja orła wyobrażonego w polu czwartym. Jeżeli bowiem godła znajdujące się w lewej pobocznicy tarczy miałyby odnosić się do Zapolyów, wyobrażony tam orzeł nie mógłby być Orłem koronnym. Rozwiązanie tego problemu przynosi genealogia królowej, która pochodziła ze związku Stefana Zapolyi z księżną piastowską Jadwigą cieszyńską. Matka królowej konsekwentnie używała na swych pieczęciach wyobrażenia piastowskiego nieukoronowanego Orła, nie łącząc go z herbem męża ${ }^{85}$. Możemy zatem przyjąć, że orzeł pojawiający się w lewej pobocznicy to piastowski Orzeł książąt cieszyńskich. Godło to nie weszło do zespołu herbów używanych przez braci Barbary. W przypadku królowej możemy się jednak domyślać jego szczególnej roli: w połączeniu z wilkiem Zapolyów przynosił jasny komunikat o jej genealogii, wskazujący jednocześnie na jej związki z dynastią, która odegrała szczególną rolę w dziejach Polski. Pochodzenie Zapolyanki „ze starej krwi królów polskich” podkreślał już Krzycki w epitalamium na ślub Zygmunta z Barbarą ${ }^{86}$. Sądzę, że podobne treści ideowe prezentuje herb Barbary Zapolyi wyobrażony na wspomnianym drzeworycie z 1515 r. Z tym, że umieszczony tam Orzeł występuje w podwójnej roli. Twórca kompozycji wykorzystał moim zdaniem formalną identyczność znaków Piastów i Jagiellonów dla zilustrowania z jednej strony związków Barbary z Piastami (pole drugie tarczy herbowej z reguły zajmował herb macierzysty, kiedy herby koronowanych małżonków poprzedzały herby królowych), z drugiej zaś mariażu Barbary z Zygmuntem. Efekt ten osiągnięto przez uzupełnienie wyobrażenia Orła o koronę niewystępującą w heraldyce Piastów cieszyńskich, choć, co należy podkreślić, nieobcą

${ }^{82}$ Na podstawie materiału źródłowego udało się ustalić pięć pieczęci używanych przez Izabelę, w tym dwie pieczęcie sygnetowe, z których jedna jest jej pieczęcią królewieńską. Pozostałe mają charakter pieczęci większych. Pierwsza z nich, poświadczona odciskiem z 1551 r., wyobraża czwórdzielną tarczę, w której w polach pierwszym i czwartym znajdują się herby Zapolyów (wilk i jednorożec), a w drugim i trzecim herby dynastyczne: jagielloński Orzeł i Wąż Sforzów (Wolfenbüttel, Niedersächsische Landesarchiv, 1 Alt 23, nr 111, k. 31). Druga, znana z lat 40. XVI w. (Sybin, Arhivele Naționale ale României [dalej: ANR], Magistratul oraşului şi scaunului Sibiu, Colecţia de documente medievale, Seria U IV, Nr. 374) i 1559 (Sybin, ANR, Colecția de documente ale parohiilor evanghelice C.A. Sătești, Preluarea 1, Seria 1 - Acte, Parohia Movile, Nr. 7), w koroboracjach nazywana jest pieczęcią autentyczną (sigillum authenticum) królowej. Wyobraża w polu pieczęci czteropolową tarczę herbową. W polu pierwszym, czwórdzielnym połączono herby węgierskie z herbami Zapolyów, w polu drugim i trzecim znajdują się odpowiednio jagielloński Orzeł i Wąż Sforzów, w polu czwartym zaś trzy lwie głowy (herb Bośni). Pieczęć ta jest najczęściej przywoływana w literaturze; zob. L. Szinvay, Beatrix és Izabella királynék pecsétei, s. 68-69; E. Veress, Izabella Kiralyine 1519-1559, Budapest 1901, s. 295, fig. 89; K. Szerląg, Pieczęć opolska królowej Izabeli, „Biuletyn Numizmatyczny”, 1969, nr 42-43, s. 808-811; tenże, Heraldyczne błędy w pieczęci królowej Izabeli, „Biuletyn Numizmatyczny”, 1969, nr 47-48, s. 889-893; É. Gyulai, A Szapolyai-címer, s. 150, fig. 21. Ostatnia pieczęć Izabeli, nazywana w koroboracjach pieczęcią sądową (sigillum iudicale), wyobraża w polu pieczęci czteropolową tarczę herbową, z herbami dynastycznymi Orłem jagiellońskim i Wężem Sforzów w polach pierwszym i czwartym oraz herbami Zapolyów (wilkiem i jednorożcem) w polach drugim i trzecim. Pojawia się ona ok. 1557 r. (Kluż, ANR, Fond familial Béldi, Seria 1 - Documente medievale, Nr. 88) i była używana do końca panowania (oryg.: Kluż, ANR, Fond familial Suky, Seria 1 - Documente medievale, Nr. 487; literatura: E. Veress, Izabella Kiralyine, s. 442, fig. 133).

83 Zob. O. Posse, Die Siegel, t. 3, Dresden 1912, s. 22, Taf. 33, Nr. 8.

${ }^{84}$ Zob. wyżej, przyp. 28.

${ }^{85}$ Zob. S.A. Sroka, Jadwiga Zapolya, s. 31 (pieczęć większa); Z. Bándi, A Magyar Országos Levéltár Jagelló-kori pecsétkiállitásának katalógusa, s. 116, nr 117 (pieczęć sygnetowa).

${ }^{86}$ A. Krzycki, Epithalamion Sigismundi regis et Barbarae reginae Poloniae, w: Andrae Cricii carmina, s. 23, nr II; B. Przybyszewski, Barbara Zapolya, s. 36 (w thum. autora). 


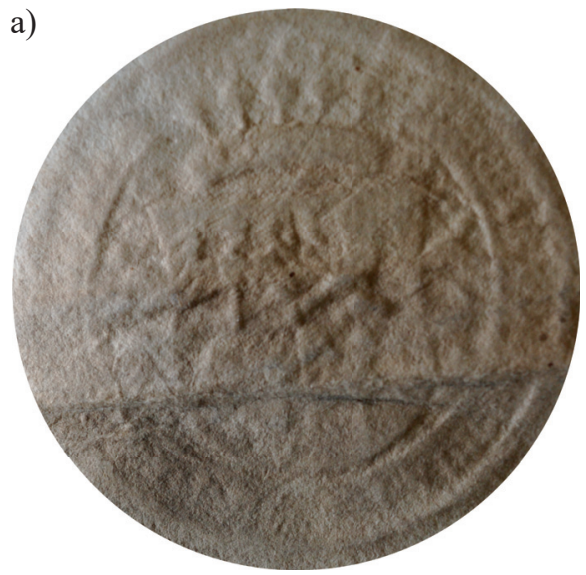

b)

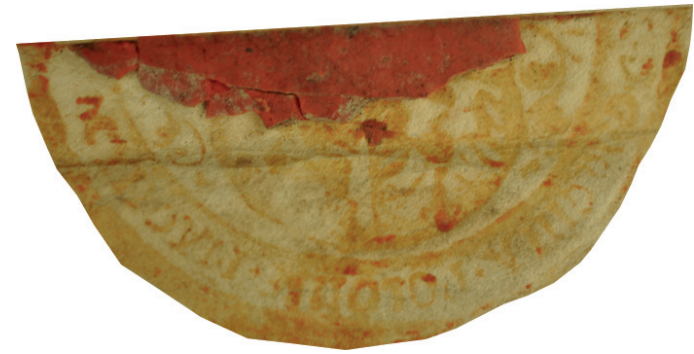

Il. 5. Pieczęć królowej Barbary Zapolyi: a) awers odcisku i b) rewers kustodii (w lustrzanym odbiciu); AP Gdańsk, Akta miasta Gdańska, 300, D/5, 791, fot. M. Hlebionek

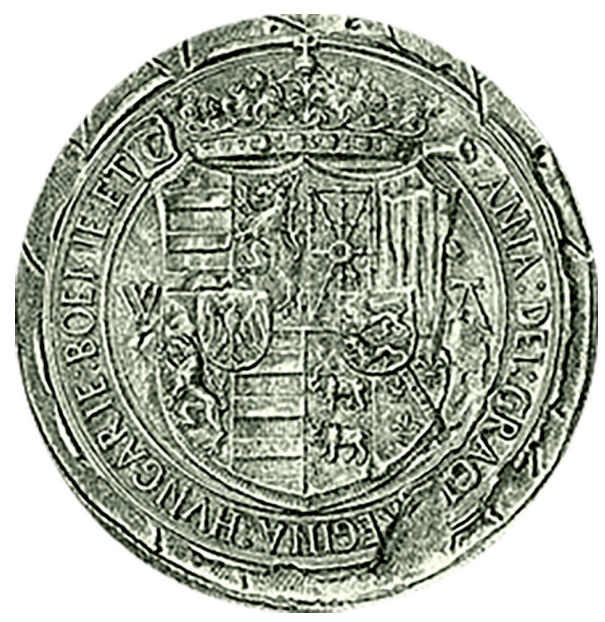

I1. 6. Pieczęć Anny de Foix, żony Władysława II Jagiellończyka; odrys za: V. Fraknói, Werbőczi István 1458-1541, Budapest 1899, s. 109, fig. 41
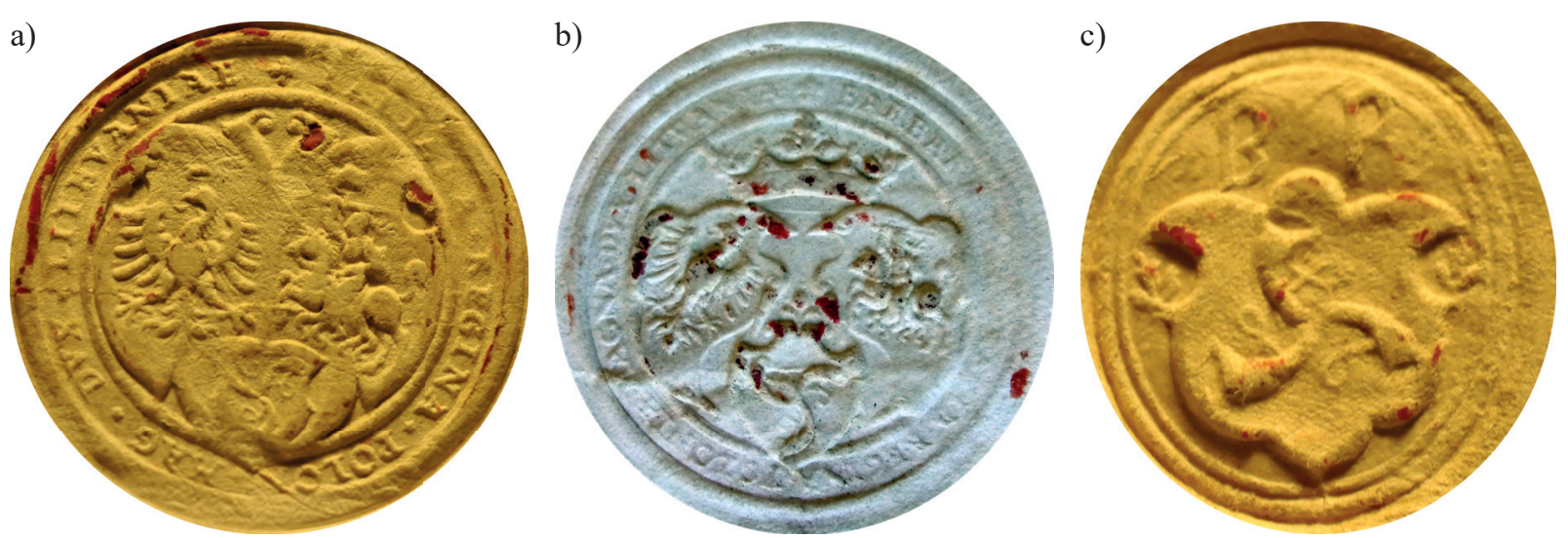

Il. 7. Pieczęcie Barbary Radziwiłłówny: a), c): AGAD, Archiwum Warszawskie Radziwiłów, dz. III, sygn. 29;

b) Berlin-Dahlem, Geheimes Staatsarchiv Preußischer Kulturbesitz, Herzogliches Briefarchiv, B1, k. 307, nr 511; fot. M. Hlebionek 
przecież heraldyce piastowskiej. Ze względu na brak szczegółowych badań trudno orzec, czy eksponowanie piastowskich koneksji miało jeszcze znaczenie dla legitymizacji władzy Jagiellonów, przez nawiązanie do piastowskiej tradycji, dobrze czytelne $\mathrm{w} \mathrm{XV} \mathrm{w.}{ }^{87} \mathrm{Z}$ pewnością jednak służyło budowie prestiżu królowej, pochodzącej wszak z rodziny niedynastycznej. Włączenie do jej herbu piastowskiego Orła stanowiło więc swoiste udostojnienie znaku. Z punktu widzenia rodzeństwa Barbary, aktywnego na Węgrzech, piastowskie pochodzenie matki nie miało aż takiego znaczenia. Dlatego odniesienia do herbu Piastów nie pojawiają się w ich heraldyce ${ }^{88}$. Z dzisiejszego punktu widzenia wyobrażenie piastowskiego Orła na pieczęci królowej nabiera dodatkowego waloru symbolicznego: Barbara była bowiem, choć po kądzieli, ostatnią przedstawicielką Piastów na tronie polskim ${ }^{89}$.

Rozwiązania zastosowane na pieczęci Barbary w zakresie heraldyki na tle XV-wiecznych pieczęci królowych polskich stanowią novum. Oprócz wprowadzenia korony czy tarczy wielopolowej zmienia się także struktura znaczeniowa znaku umieszczonego na pieczęci. Dobrze ilustruje to dokonane wyżej zestawienie pieczęci Barbary z pieczęcią Zofii Holszańskiej. Zofia w sferze heraldyki odwoływała się do herbów męża oraz - na pierwszej pieczęci - do jednostkowego wyróżnika w postaci inicjału imienia. Barbara, w świetle znanych źródeł, jako pierwsza wprowadziła do zespołu herbów prezentowanych na pieczęci godło niedynastyczne - wilka Zapolyów. Jest to zaskakujące o tyle, że - jak zauważa A. Stieldorf - pieczęcie królowych bardziej niż pieczęcie królewskie (ukazujące przede wszystkim godność dysponenta) zorientowane były na podkreślanie pozycji społecznej dysponentki ${ }^{90}$. Stąd królowe pochodzące z dynastii kładły w polu pieczęci swe herby rodowe i terytorialne, które w połączeniu ze znakami męża stanowiły ilustrację zawartych aliansów politycznych ${ }^{11}$. Inaczej były rozłożone akcenty w przypadku pieczęci władczyń niedynastycznych. Tu nie zawsze można mówić o sojuszach ważnych z punktu widzenia monarchii, choć mogły one przynosić określone korzyści rodzinie królowej, a czasem i monarchii. Podkreślanie niedynastycznego pochodzenia nie musiało leżeć zaś w interesie ani królowych, ani ich koronowanych mężów, stało bowiem w sprzeczności z obowiązującą w ówczesnym społeczeństwie niepisaną zasadą równości współmałżonków ${ }^{92}$. I był to chyba jeden z czynników wpływających na pominięcie herbu rodowego w sfragistyce Holszańskiej. W przypadku Barbary Zapolyi, oprócz wykorzystania rozwiązań czesko-węgierskich w sferze kompozycji wyobrażenia napieczętnego, wprowadzenie tam jej herbu rodowego być może tłumaczyć należy znaczeniem politycznym małżeństwa ${ }^{93}$, zagranicznym pochodzeniem królowej (nie była poddaną przyszłego męża, co niwelowało potencjalne konflikty ze szlachtą), ale też silniejszą pozycją społeczną kobiety na Węgrzech ${ }^{94}$. Przyjęcie, a chyba i społeczna akceptacja, wzorów zaczerpniętych ze sfragistyki władczyń dynastycznych, które widać na pieczęci Barbary, może stanowić też odzwierciedlenie zmian, jakim uległa pozycja królowej na przestrzeni XV w. ${ }^{95}$ Pieczęcie Barbary Zapolyi, ale też nieco późniejsze pieczęcie Barbary Radziwiłłówny, wskazują na silniejsze ${ }^{96}$

${ }^{87}$ P. Węcowski, Dwa przyczynki do piastowskiej legitymizacji władzy Jagiellonów. Imiona i liczebniki w tytulaturze polskich Jagiellonów, w: Świat średniowiecza. Studia ofiarowane Profesorowi Henrykowi Samsonowiczowi, red. A. Bartoszewicz i in., Warszawa 2010, s. 562-576.

${ }^{88}$ É. Gyulai, A Szapolyai-címer, s. 130-158.

${ }^{89}$ W. Pociecha, Barbara Zapolya, s. 294.

90 A Stieldorf, Die Siegel der Herrscherinnen, s. 24.

91 E. Danbury, Queens and Powerful Women, s. 20.

92 D. Mrówczyńska, Wzorzec społeczny, s. 61; T. Szulc, Niedynastyczne malżeństwa Jagiellonów, s. 243; tenże, Nierówność stanowa, s. 135-140.

${ }^{93}$ W kontekście Barbary Zapolyi znaczenie polityczne małżeństwa dla jego akceptacji przez społeczeństwo podkreśla D. Mrówczyńska, Wzorzec społeczny, s. 61.

94 M. Bogucka, Białogłowa $w$ dawnej Polsce. Kobieta w społeczeństwie polskim XVI-XVIII wieku na tle porównawczym, Warszawa 1998, s. 224.

${ }^{95}$ Stan polskich badań nad zagadnieniem statusu społecznego i roli politycznej żon władców omawia M. Piber-Zbieranowska, Żony Piastów mazowieckich. Znaczenie księżnych w późnym średniowieczu (XIV-XVI w.), w: Dziedzictwo Piastów mazowieckich, s. 127-129. Tam też odesłania do wcześniejszych publikacji.

${ }^{96}$ Znamy obecnie trzy pieczęcie Barbary Radziwiłłówny używane przez nią w czasie małżeństwa z Zygmuntem Augustem: dwie większe i jedną sygnetową. Pierwsza z pieczęci większych pozostawała w użyciu w okresie poprzedzającym koronację Barbary. Mierzy ona $36 \mathrm{~mm}$ średnicy, a wyobraża w polu pieczęci trzy fantazyjne tarcze herbowe w układzie 2 / 1. W tarczy 
niż w czasach Zofii Holszańskiej upodmiotowienie królowych o niedynastycznym pochodzeniu w sferze symboliki władzy.

Z punktu widzenia semiotyki antropologicznej ważne jest, że uwzględnianie na pieczęciach królowych herbów rodowych wzmacniało przekaz budujący ich tożsamośćc ${ }^{77}$. Pieczęcie Zofii pokazują, że dotąd (w kontekście symboliki władzy) tożsamość królowych budowana była przede wszystkim na podstawie autorytetu męża. Natomiast pieczęcie obu Barbar, rozszerzając ów przekaz, ukazują je jako osoby pochodzące z określonego kręgu społecznego, posiadające własną genealogię - pochodzenie, którego nie musiały ukrywać. Pytaniem otwartym pozostaje, na ile wpływ na akceptację takiej konstrukcji pieczęci miała osobowość młodej żony Zygmunta I oraz jej podporządkowanie się oczekiwaniom społecznym w pozostałych sferach aktywności ${ }^{98}$. Nie ulega jednak wątpliwości, że pieczęć Barbary Zapolyi stała się precedensem przygotowującym grunt pod późniejsze pieczęcie Barbary Radziwiłłówny, której osoba budziła u współczesnych większe kontrowersje.

\section{Aneks \\ Zestawienie legend pieczęci królowych Polski ${ }^{99}$}

1. Pieczęć majestatowa królowej Jadwigi, legenda wykonana minuskułą gotycką: [S] HEDWIGIS · DEI - GRATIA - REGINE - POLONIE - NECNON $\cdot$ TERRARV $(m):$ CRACOV[IE $\cdot$ SANDOMI]RIE $\cdot$ SYRADIE[ $\cdot$ LAN]CICIE $\cdot$ CVIAVIE $\cdot$ POMORANIE $\vdots$ Q $(v e) ~:$ $\mathrm{D}($ omi $) \mathrm{N}(e)$

2. Pieczęć większa (trójherbowa) królowej Jadwigi, legenda wykonana minuskułą gotycką: * S: HEDWIGIS : D(ei) : G(racia) : REGINA : POLON/IE: PRINCEPS : LITVANIE : SUP(re)MA :

3. Pieczęć średnia (dwuherbowa) królowej Jadwigi, legenda wykonana majuskułą gotycką z domieszką liter minuskulnych (litera h w imieniu królowej oraz litery n, e w całej inskrypcji):

: S $\cdot$ HEDEWIGIS (!) $\cdot$ DEI $\cdot$ GRACIA $\cdot$ REGINE $\cdot$ POLONIE $\cdot$ ET (cetera)

4. Pieczęć średnia (dwuherbowa) druga królowej Jadwigi, legenda wykonana minuskułą gotycką:

$+\mathrm{S} \cdot \mathrm{HEDWIGIS} \cdot \mathrm{DEI} \cdot \mathrm{GRA}(\mathrm{cia}) \cdot \mathrm{REGINE} \cdot \mathrm{POLONIE}[\ldots]$ LITVANIE $\cdot$ TC $(=$ et cetera $)$

5. Pieczęć mniejsza królowej Jadwigi, legenda wykonana minuskułą gotycką:

$+\mathrm{S}$ HEDWIGIS RE/GINE · POLONIE :

6. Pierwsza pieczęć królowej Zofii Holszańskiej, legenda wykonana minuskułą gotycką:

$+\mathrm{S} \cdot \mathrm{ZOPHIA} \cdot \mathrm{DEI} \cdot \mathrm{GRACIA} \cdot \mathrm{REGINA} \cdot$ POLONIE $\cdot$

7. Druga pieczęć królowej Zofii Holszańskiej, legenda wykonana minuskułą gotycką: SOPHIA DEI / GRA(cia) REGINA / POLONIE

pierwszej polski Orzeł, w tarczy drugiej litewska Pogoń, w tarczy trzeciej, nieco mniejszej, godło herbu Radziwiłłów Trąby; legenda: zob. Aneks, nr 14. Odciski, do których udało mi się dotrzeć, pochodzą z lat 1549-1550 (AGAD, Archiwum Warszawskie Radziwiłłów, dz. III, sygn. 29, k. 45, 47). Druga pieczęć większa królowej ma nieco większą średnicę (42mm) i generalnie powtarza program heraldyczny wcześniejszej, przy powiększeniu tarczy z herbem rodowym Barbary oraz ułożeniu tarcz z herbami Polski i Wielkiego Księstwa Litewskiego w ukłonie heraldycznym. Nowością jest umieszczenie ponad tarczami górnymi otwartej korony o trzech fleuronach i dwóch pałkach. W legendzie pojawia się natomiast formułka dewocyjna, której nie wprowadzono do inskrypcji wcześniejszej pieczęci; zob. Aneks, nr 15. Jak dotąd udało mi się odnaleźć jeden jej egzemplarz pochodzący z 1551 r.; GStA PK Berlin, HBA, B1, k. 307, nr 511. Niepublikowany dotąd sygnet królowej nie zawiera żadnych odniesień do jej małżeństwa z Jagiellonem, a prezentuje jedynie jej herb rodowy, nad którym umieszczono inicjały dysponentki: B / R. Jego odciski pochodzą z 1549 r.; AGAD, Archiwum Warszawskie Radziwiłłów, dz. III, sygn. 29, k. 76 (odcisk luźny); k. 5, 7, 16, 18, 20, 22, 39, 43, 55, 57, 68, 77. W sprawie wcześniejszych publikacji tych zabytków zob. wyżej, przyp. 66.

97 B. Bedos-Rezak, Women, Seals and Power, s. 72.

98 D. Mrówczyńska, Wzorzec spoleczny, s. 68.

99 Odczyt legendy podano zgodnie z zaleceniami Międzynarodowego słownika sfragistycznego; zob. Vocabulaire international de la sigillographie, red. S. Ricci-Noe, Rom 1990, s. 27-29; przekład na język polski: Vocabularium Internationale Sigillographicum, red. L. Vrtel, K. Müller, M. Hlebionek, V. Keresztes, Bratislava 2016, s. 71-73. 
8. Pierwsza pieczęć królowej Elżbiety Rakuszanki, legenda wykonana minuskułą gotycką: ELIZABETH DEI GRACIA REGINA POLONIAE MAGNA DVX LITHVANIE • SIGILLVM (? $)^{100}$

9. Druga pieczęć królowej Elżbiety Rakuszanki, legenda wykonana minuskułą gotycką: S ELIZABETH DEI GRA(cia) REGINA POLONIE MAGNA DUX LITHWANIE

10. Pieczęć królowej Heleny Iwanowny, liternictwo nieznane: [...] POLO(n)IE MAGNA DUCIS(sa). LITUAN(ie). RUS(sie) : PRUSS(ie).

11. Pieczęć królowej Barbary Zapolyi, legenda wykonana kapitałą protorenesansową: [BARBAR]A $\cdot \mathrm{D}(e i) \cdot \mathrm{G}($ racia $) \cdot \mathrm{REGINA} \cdot \mathrm{POLONIE} \cdot \mathrm{MAGNA} \cdot \mathrm{DVX} \cdot[$ LITHVANIE ETC $($ etera $)$ ]

12. Pieczęć królowej Bony Sforzy, legenda wykonana kapitałą:

* BONA $\cdot \operatorname{SFOR}(z a) \cdot \operatorname{ARAG}(o n a) \cdot \mathrm{D}(e i) \cdot \mathrm{G}($ ratia $) \cdot \mathrm{REGINA} \cdot \mathrm{POLONIE} \cdot \mathrm{MA}(g n a) \cdot \mathrm{DVX}$ - LITVANIE

13. Pieczęć większa królowej Elżbiety Habsburżanki, legenda wykonana kapitałą: * ELISABETH REGINA POLON(iae) $\cdot \operatorname{MAG}(n a) \cdot$ DVX LITHVANIAE

14. Pieczęć większa pierwsza królowej Barbary Radziwiłłówny, legenda wykonana kapitałą: + BARBARA $\cdot$ REGINA $\cdot \operatorname{POLON(iae)} \cdot \operatorname{MAG}(n a) \cdot$ DUX $\cdot$ LITHVANIAE

15. Pieczęć większa druga królowej Barbary Radziwiłłówny, legenda wykonana kapitałą:

* BARBARA · DEI - GRACIA · REGINA · POLONIAE · MAGNA · DVX · LITHVANIAE

16. Pieczęć większa królowej Katarzyny Habsburżanki, legenda wykonana kapitałą: $\mathrm{KATERINA} \cdot \mathrm{D}($ ei $) \cdot \mathrm{G}(\mathrm{racia}) \cdot \mathrm{REGINA} \cdot \mathrm{POLONIE} \cdot \mathrm{M}(a g n a) \cdot \mathrm{D}(v x) \cdot \mathrm{LITHVANIE} \cdot \mathrm{ETC}($ etera $) \cdot$

17. Pieczęć mniejsza królowej Katarzyny Habsburżanki, legenda wykonana kapitałą: KATERINA : $\mathrm{D}(e i)$ : $\mathrm{G}($ racia $)$ : $\mathrm{RE}($ gina $)$ : $\mathrm{POLO}($ nie $)$ : $\mathrm{M}($ agna $)$ : $\mathrm{D}(v x) \mathrm{LIT}($ vanie $)$ : ETC(etera $)$

\title{
An unknown seal of Queen Barbara Zápolya compared with the sphragistics of spouses of Polish kings from the Jagiellonian dynasty
}

\begin{abstract}
Summary: The seals of Polish queens have rarely been the subject of separate studies. Yet, they offer extremely important material for reflections on the symbols of monarchical power and the status and identity of their holders. So far, we have known ten seals used between the end of the fourteenth and the mid-sixteenth century by the wives of successive Jagiellons (excluding the wives of King Sigismund Augustus). The most numerous among them was the sphragistic system of Queen Jadwiga, who had at least six types of seals. Other queens had one or two seals. Initially, the dominant among them were seals bearing two coats of arms of the state or state and dynastic ones. The three- and one-coat-of-arms systems were less common. Only the seals of Elizabeth of Austria (the wife of King Casimir IV) had six shields with dynastic and state coats of arms. The seals of Queen Helena of Moscow (the wife of Alexander Jagiellon) and Queen Bona Sforza (second wife of Sigismund I the Old), using a multi-field shield, were a novelty. The seal of Queen Barbara Zápolya (1496-1515), the first wife of King Sigismund I, has so far belonged to a collection of seals unknown to researchers. The seal's impression has been preserved on a letter the queen addressed to the authorities of Gdańsk. The seal measures $49 \mathrm{~mm}$ in diameter, and its legend can be reconstructed in the following form: [BARBAR]A - D $(e i)-\mathrm{G}($ racia $)$ - REGINA - POLONIE - MAGNA - DVX - [LITHUANIE ETC]. Under the crown, there is an open bipartite shield in a column, with the coats of arms of the Crown and Lithuania on the right side and the queen's personal emblems (the Wolf of Zápolya and the Eagle of the Teschen Piasts) on the left side. The composition of the queen's seal clearly differs from the solutions known from the seals of her predecessors on the Polish throne, showing at the same time significant similarities to the seals of the wives of King Vladislaus II Jagiellon of Bohemia and Hungary. The reference in the queen's coat of arms to the Piast Eagle, which is absent in the seals of her siblings active in Hungary, served to build up the queen's prestige as a person from a non-dynastic family. The juxtaposition of Barbara Zápolya's seals with those of Sophia of Halshany (the fourth and last wife of Władysław II Jagiello,
\end{abstract}

${ }^{100}$ Przyjęcie takiej lekcji powoduje, że incipit legendy musi zostać przesunięty w lewo względem pionowej osi odcisku. Ze względu na słabą czytelność części inskrypcji należy dopuścić brzmienie tego jej fragmentu w innej formie, np. prezentującej ruską tytulaturę królowej. 
also not from the ruling dynasty), shows increased empowerment of the queen of non-dynastic origin in the symbolism of the queen's power of non-dynastic origin compared to that of the times of Queen Sophia. Drawing on patterns from the sphragistics of dynastic rulers, which can be seen on Barbara's seal, may reflect the evolution that the position of the Polish queen underwent throughout the fifteenth century.

Nota o autorze: Marcin Hlebionek, dr hab., prof. UMK, pracownik Katedry Historii Średniowiecza i Nauk Pomocniczych Historii Instytutu Historii i Archiwistyki Uniwersytetu Mikołaja Kopernika w Toruniu. Zainteresowania badawcze oscylują wokół nauk pomocniczych historii średniowiecznej i nowożytnej, głównie sfragistyki, archiwistyki oraz historii średniowiecznej i regionalnej, ze szczególnym uwzględnieniem ziem nadnoteckich.

Author: Marcin Hlebionek, professor at the Nicolaus Copernicus University in Torun, employee of the Department of Mediaeval History and Auxiliary Sciences of History at the Institute of History and Archival Studies of Nicolaus Copernicus University in Torun. His research interests focuses on auxiliary sciences of medieval and modern history, mainly sphragistics, archival science, and medieval and regional history, with particular emphasis on the lands on the Noteć River.

Instytut Historii i Archiwistyki Uniwersytetu Mikołaja Kopernika

ul. Bojarskiego 1

87-100 Toruń

e-mail: hleb@umk.pl

\section{Bibliografia}

Bedos-Rezak B., Women, Seals and Power in Medieval France 1150-1350, w: Women and Power in the Middle Ages, red. M. Erler, M. Kowaleski, Athens-London 1988, s. 61-82

Czwojdrak B., Zofia Holszańska. Studium o dworze i roli królowej w późnośredniowiecznej Polsce, Warszawa 2012

Danbury E., Queens and Powerful Women. Image of Authority, w: Good Impressions. Image and Authority in Medieval Seals, red. N. Adams, J. Cherry, J. Robinson, London 2008, s. 17-24

Gumowski M., Pieczęcie królowych, w: M. Gumowski, M. Haisig, S. Mikucki, Sfragistyka, Warszawa 1960, s. $184-185$

Gyulai É., Carmina in arma Zapolyana. Címversek Szapolyai Borbála lengyel királyné (1512) és Szapolyai János Zsigmond választott király (1567) címeréröl, „Publicationes Universitatis Miskolciensis. Sectio Philosophica”, 9, 2004, nr 4, s. 61-81

Lukanc M., Anna of Celje (Cilli). In Search of the Overlooked Queen, w: Papers and Proceedings of the Third Medieval Workshop in Rijeka, red. K. Jovanowić, S. Miljan, Rijeka 2018, s. 69-86

Mahnič K., Srednjeveški ženski pečati iz Arhiva Republike Slovenije, Ljubljana 2006

Mrówczyńska D., Wzorzec społeczny królowej w Polsce XVI wieku, w: Społeczeństwo staropolskie, t. 3, red. A. Wyczański, Warszawa 1983, s. 47-70

Piber-Zbieranowska M., Żony Piastów mazowieckich. Znaczenie księżnych w późnym średniowieczu (XIV-XVI w.), w: Dziedzictwo Piastów mazowieckich. Stan badań i postulaty badawcze, red. J. Grabowski, R. Mroczek, P. Mrozowski, Warszawa 2017, s. 127-140

Piech Z., Monety, pieczęcie i herby w systemie symboli władzy Jagiellonów, Warszawa 2003

Piech Z., Pieczęcie herbowe w systemach sfragistycznych dawnej Rzeczpospolitej, w: Dawne pieczęcie. Typologia - metody badań - interpretacje, red. Z. Piech, Warszawa 2015, s. 207-253

Pociecha W., Barbara Zapolya, w: PSB, t. 1, Kraków 1935, s. 293-294

Przybyszewski B., Barbara Zapolya, królowa Polski 1512-1515, Łańcut 2000

Rabiej P., Užmirštas paminklas. 1425 m. krikštykla Krokuvos Šv. Stepono bažnyčioje, w: Jogailos ir Vytauto laikai Moksliniu straipsniu rinkinys, skirtas Žalgirio mūšio 600-osioms metinèms, red. Z. Kiaupa i in., Kaunas 2011, s. 170-186

Rekettyés M., Adalékok Szapolyai Borbála lengyel királyné trónrajutásának előzményeihez és uralkodásához, „Publicationes Universitatis Miskolcinensis. Sectio Philosophica”, 9, 2004, nr 4, s. 119-135

Rutkowska G., Dwór polskich królowych Anny Cylejskiej i Elżbiety Granowskiej, w: Narodziny Rzeczypospolitej. Studia z dziejów średniowiecza i czasów wczesnonowożytnych, t. 2, red. W. Bukowski, T. Jurek, Kraków 2012, s. 869-914 
Sigilla regum et reginarum Poloniae. Pieczęcie królów i królowych Polski ze zbiorów Archiwum Głównego Akt Dawnych, Warszawa 2015

Sroka S.A., Jadwiga Zapolya. Piastówna ślaska na Węrzzech w dobie panowania Jagiellonów, Kraków 2011 Stieldorf A., Die Siegel der Herrscherinnen. Siegelführung und Siegelbild der ,,deutschen” Kaiserinnen und Königinnen, „Rheinische Vierteljahrsblätter”, 64, 2000, s. 1-44

Stróżyk P., Tablica herbowa z kościoła Bożego Ciała w Poznaniu, w: Memoria viva. Studia historyczne poświęcone pamięci Izabeli Skierskiej (1967-2014), red. A. Gąsiorowski, G. Rutkowska, Poznań 2015, s. 771-773

Sułkowska-Kurasiowa I., Dokumenty królewskie i ich funkcja w państwie polskim za Andegawenów i pierwszych Jagiellonów 1370-1444, Warszawa 1977

Sułkowska-Kurasiowa I., Polska kancelaria królewska w latach 1447-1506, Wrocław-Warszawa-Kraków 1967

Szulc T., Niedynastyczne matżeństwa Jagiellonów i królów elekcyjnych, w: Nil nisi veritas. Księga dedykowana Profesorowi Jackowi Matuszewskiemu, red. M. Głuszak, D. Wiśniewska-Jóźwiak, Łódź 2016, s. 243-274

Węcowski P., Jadwiga Andegaweńska w opinii prawniczej z końca XV wieku. Przyczynek do późnośredniowiecznych wyobrażeń na temat władzy monarszej, w: Ecclesia - regnum - fontes. Studia z dziejów średniowiecza, red. S. Gawlas, K. Gołąbek, M. Janicki in., Warszawa 2014, s. 250-257 